\title{
The link between atmospheric radicals and newly formed particles at a spruce forest site in Germany
}

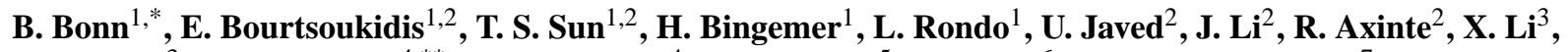 \\ T. Brauers ${ }^{3}$, H. Sonderfeld ${ }^{4, *}$, R. Koppmann ${ }^{4}$, A. Sogachev ${ }^{5}$, S. Jacobi ${ }^{6}$, and D. V. Spracklen ${ }^{7}$ \\ ${ }^{1}$ Institute for Atmospheric and Environmental Sciences, Goethe University, Frankfurt, Germany \\ ${ }^{2}$ Air Chemistry Department, Max-Planck-Institute for Chemistry, Mainz, Germany \\ ${ }^{3}$ Institute for Energy and Climate Research, IEK-8, Research Center, Jülich, Germany \\ ${ }^{4}$ Physics Department, University of Wuppertal, Wuppertal, Germany \\ ${ }^{5}$ Wind Energy Department, Technical University of Denmark, Roskilde, Denmark \\ ${ }^{6}$ Hessian Agency for the Environment and Geology, Wiesbaden, Germany \\ ${ }^{7}$ Institute for Climate and Atmospheric Science, School of Earth and Environment, University of Leeds, Leeds, UK \\ *now at: Institute for Advanced Sustainability Studies, Potsdam, Germany \\ *** now at: Atmospheric Chemistry Group, Department of Chemistry, University of Leicester, Leicester, UK
}

Correspondence to: B. Bonn (boris.bonn@iass-potsdam.de)

Received: 5 September 2013 - Published in Atmos. Chem. Phys. Discuss.: 24 October 2013

Revised: 4 September 2014 - Accepted: 9 September 2014 - Published: 15 October 2014

\begin{abstract}
It has been claimed for more than a century that atmospheric new particle formation is primarily influenced by the presence of sulfuric acid. However, the activation process of sulfuric acid related clusters into detectable particles is still an unresolved topic. In this study we focus on the PARADE campaign measurements conducted during August/September 2011 at Mt Kleiner Feldberg in central Germany. During this campaign a set of radicals, organic and inorganic compounds and oxidants and aerosol properties were measured or calculated. We compared a range of organic and inorganic nucleation theories, evaluating their ability to simulate measured particle formation rates at $3 \mathrm{~nm}$ in diameter $\left(J_{3}\right)$ for a variety of different conditions. Nucleation mechanisms involving only sulfuric acid tentatively captured the observed noon-time daily maximum in $J_{3}$, but displayed an increasing difference to $J_{3}$ measurements during the rest of the diurnal cycle. Including large organic radicals, i.e. organic peroxy radicals $\left(\mathrm{RO}_{2}\right)$ deriving from monoterpenes and their oxidation products, in the nucleation mechanism improved the correlation between observed and simulated $J_{3}$. This supports a recently proposed empirical relationship for new particle formation that has been used in global models. However, the best match between theory and measurements for the site of interest was found for an activation process
\end{abstract}

based on large organic peroxy radicals and stabilised Criegee intermediates (sCI). This novel laboratory-derived algorithm simulated the daily pattern and intensity of $J_{3}$ observed in the ambient data. In this algorithm organic derived radicals are involved in activation and growth and link the formation rate of smallest aerosol particles with $\mathrm{OH}$ during daytime and $\mathrm{NO}_{3}$ during night-time. Because the $\mathrm{RO}_{2}$ lifetime is controlled by $\mathrm{HO}_{2}$ and $\mathrm{NO}$ we conclude that peroxy radicals and NO seem to play an important role for ambient radical chemistry not only with respect to oxidation capacity but also for the activation process of new particle formation. This is supposed to have significant impact of atmospheric radical species on aerosol chemistry and should be taken into account when studying the impact of new particles in climate feedback cycles.

\section{Introduction}

The formation of new particles by gaseous molecules has been observed in and above a variety of different forest ecosystems (Kulmala et al., 2004d). Newly formed particles are frequently able to grow to sizes at which they can be activated as cloud droplets (particle diameter $D_{\mathrm{p}}>60 \mathrm{~nm}$ ), 
so influencing the brightness and lifetime of clouds. It has been suggested that biogenic emissions from forests are involved in new particle formation and growth, meaning that forests could impact climate through aerosol-cloud interactions. Previous studies have suggested that the magnitude of this effect could be substantial, with Spracklen et al. (2008) estimating that monoterpene emissions from boreal forests cause between 1.8 and $6.4 \mathrm{~W} \mathrm{~m}^{-2}$ of regional cooling through the aerosol indirect effect. Therefore a new climate feedback process linking forest emissions, aerosol and climate effects has been proposed (Kulmala et al., 2004d; Bonn et al., 2008, 2009; Carslaw et al., 2010; Paasonen et al., 2013). For both steps involved in new particle formation, i.e. nucleation and first steps of growth, knowledge of the chemical composition and the controlling parameters for the initial size range (particle diameter $D_{\mathrm{p}}<10 \mathrm{~nm}$ ) are essential but so far unidentified.

A number of studies focusing on detailed understanding and explanation of atmospheric nucleation processes have been conducted in order to elucidate the key parameters driving and controlling new particle formation (NPF) (Hyvönen et al., 2005; Kulmala et al., 2004a, b, c; Bonn and Moortgat, 2003; Bonn et al., 2008, 2009; Mauldin III et al., 2013). However, the current impossibility to chemically analyse the tiny and chemically unstable aerosol particles (see Sect. 2 for reasoning $)$ at their smallest size $(\approx 1.5 \mathrm{~nm}$ in diameter $)$ complicates the identification of the nucleation initiating molecules or compounds (NIM) and the compounds needed for the initial activation and growth. This initial activation is thought to be controlled by the presence of air ions (Laakso et al., 2006) or by strong chemical interactions of participating molecules such as sulfuric acid. Some previous studies have focused on sulfuric-acid-related explanations only (Weber et al., 1999; Laakso et al., 2006; Riipinen et al., 2007; Paasonen et al., 2012; Mauldin III et al., 2013), whereas other theories rely on iodine oxides (Burkholder et al., 2004; O'Dowd and Hoffmann, 2005), organic substances (Bonn and Moortgat, 2003), or a mixed approach of organic and inorganic species (Kulmala et al., 2004a, b; Bonn et al., 2008). For example, Bonn and Moortgat (2003) have suggested that sesquiterpenoid products initiate nucleation.

To find indications of the nucleation mechanism, indirect approaches involving correlations between particle formation rate (typically either at $3 \mathrm{~nm}\left(J_{3}\right)$ or at $1 \mathrm{~nm}\left(J_{1}\right)$ in diameter) and ambient gas-phase concentrations have been applied. A number of studies have explored the relationship between particle formation rate and the concentration of gaseous sulfuric acid for the SMEAR II boreal forest site in Hyytiälä (Southern Finland) as well as for other locations (Kulmala et al., 2006; Sihto et al., 2006; Riipinen et al., 2007; Zhang et al., 2012). The correlations appear to be environment dependent, with relationships linking sulfuric acid concentration $\left[\mathrm{H}_{2} \mathrm{SO}_{4}\right]$ and $J_{3}$ involving sulfuric acid to the power of between unity and two (Kulmala et al., 2006; Sihto et al., 2006; Riipinen et al., 2007; Nieminen et al., 2012) mul- tiplied by empirically derived pre-factors (i.e. $A$ or $K$ ) that vary spatially and temporally by orders of magnitude (Kulmala et al., 2006; Sihto et al., 2006; Riipinen et al., 2007). These empirically derived pre-factors are assumed to include the lumped kinetics of particle formation as well as further species contributing to the initial steps of particle growth (Bonn et al., 2008). The most recent empirical formulation for the boreal forest site in Hyytiälä (Finland) is provided by Nieminen et al. (2012). Nonetheless, the detailed meaning and understanding of the formation process remains an open question.

One challenge in this context is the correlation between a variety of different substances, especially those linked through a similar method of production or destruction. For example, sulfuric acid is highly correlated with the atmospheric oxidant $\mathrm{OH}$, which is directly linked to solar radiation intensity. $\mathrm{OH}$ controls the oxidation of most atmospheric compounds, therefore linking a host of organic compounds to the concentration of $\mathrm{OH}$ and sulfuric acid. This complicates correlations between different atmospheric species, with individual correlations being difficult to interpret without observations of an entire set of atmospheric species. Therefore a good correlation is neither a proof nor a disproof of a compound's particular role in the nucleation process.

Here we investigate a novel potential link between the new particle formation process and ambient radicals. These radicals are expected to increase the nucleus size through chemical reactions that enable the cluster to overcome the critical nucleation size. The primary candidates for these heterogeneous reactions (NIM or cluster and radical), are organic peroxy radicals from terpene oxidation (Bonn et al., 2007; Wolf et al., 2009, 2011). If this is the case, it is likely that the entire formation process is controlled by a number of different compounds - i.e. ambient inorganic and organic radicals such as hydroxyl radical $(\mathrm{OH})$, hydroperoxy radicals $\left(\mathrm{HO}_{2}\right)$, nitrogen monoxide $(\mathrm{NO})$, the nitrate radical $\left(\mathrm{NO}_{3}\right)$ and different organic peroxy radicals $\left(\mathrm{RO}_{2}\right)$. These are key species for representing different atmospheric chemistry situations i.e. nitrogen oxides $\left(\mathrm{NO}_{\mathrm{x}}\right)$ and $\mathrm{VOC}$ control, the impact of radiation and temperature and of biosphere atmosphere interactions.

\section{Theoretical background}

New aerosol particles are formed from gaseous conversion forming an amorphous new phase (Pankow, 1994). Therefore a non-volatile and supersaturated gas-mixture is usually considered (Friedlander, 2000; Jacobson, 2005; Seinfeld and Pandis, 2006). In this context we will distinguish between two different rates: the nucleation and the formation rate of new particles. As nucleation describes the novel production of a new phase with a distinct boundary between the gas- and the novel liquid or solid (aerosol) phase, the corresponding rate is named nucleation rate. In contrast, ultrafine particles 
at larger sizes may form by the split up of larger ones or by the growth of smaller ones to the apparent size. The increase in number in a certain size interval is called the formation rate and the exact value depends on the particular size of interest. As the exact starting size of a new particle relies on the compounds involved, we will focus on the formation rate at $3 \mathrm{~nm}$ in particle diameter $J_{3}$. At this size a new phase (i.e. a particle) is definitely formed independent of its chemical composition and is detectable with a commercial condensation particle counter.

The formation of clusters and particles from gaseous molecules in the atmosphere needs to overcome several nucleation hampering effects. Those include the surface production for a novel droplet or crystal and the increase of evaporation flux due to the initially remarkably curved surface (Kelvin effect) and a sufficient growth, before the clusters or smallest particles become captured by pre-existing particles. This capturing process depends on the growth rate GR (diameter per time) and the condensation (in $\mathrm{m}^{-2}, \mathrm{CS}^{\prime}$ for gas molecules) or coagulation sink (in $\mathrm{m}^{-2}$, Coag $\mathrm{S}^{\prime}$ for clusters and particles). The larger the GR (substantial mass supply), and therefore the shorter the time to survive before becoming detectable, and the smaller the $\mathrm{CS}^{\prime}$ or $\operatorname{CoagS} \mathrm{S}^{\prime}$, the higher the survival rate. These two sink terms are commonly provided in two different units: (a) in $\mathrm{s}^{-1}$ to represent the ambient lifetime of the clusters or particles before getting lost on pre-existing surfaces (Pirjola and Kulmala, 1998; Dal Maso et al., 2005) or in (b) $\mathrm{m}^{-2}$ (here denoted with an '), i.e. related to the available aerosol surface area for attachment due to diffusional collisions (Kerminen and Kulmala, 2002).

Since homogeneous homomolecular nucleation by a single compound generally requires extremely high supersaturation for any of the relevant species to overcome the barrier described by the Kelvin effect (surface curvature and elevated evaporation flux as compared to flat surfaces), it is not relevant for stable compounds except radicals at atmospheric background conditions (Friedlander, 2000; McFiggans et al., 2004). Homogeneous nucleation by multiple compounds (heteromolecular) requires a substantial interaction between compounds such as present in the binary or ternary nucleation of sulfuric acid-water and of sulfuric acid-water-ammonia or amines (Friedlander, 2000; Seinfeld and Pandis, 2006; Kirkby et al., 2011; Paasonen et al., 2012). These intermolecular interactions such as acid-base stabilisation (Kirkby et al., 2011; Ryding et al., 2012) lower the critical energy that is required to form the new particle phase. There are two further established physico-chemical effects that may cause a drop in the nucleation barrier energy: (i) the solution (Raoult) effect like in the case of watersoluble species and (ii) the ionic (Thompson) effect (Friedlander, 2000; Jacobson, 2005; Seinfeld and Pandis, 2006).

In the size range of interest the solvent mass is extremely small and even water vapour is not able to join the aerosol phase due to the Kelvin effect without considering chemical effects. One theory including this effect is the so-called
nano-Koehler theory (Kulmala et al., 2004a), which assumes that sulfuric acid and water containing clusters become activated by water-soluble organic compounds. But organic compounds of notable mass are primarily less water-soluble and the solubility effects commonly become predominant at sizes beyond $50 \mathrm{~nm}$ in diameter - sizes substantially greater than the nucleation size. Earlier investigations on the ionic effect within the boundary layer above a vegetated surface revealed a contribution of less than $0.1 \mathrm{~cm}^{-3} \mathrm{~s}^{-1}$ (Hirsikko et al., 2011) to the particle formation rate at $2 \mathrm{~nm}\left(J_{2}\right)$. This effect declines further still towards larger particle sizes because of a multitude of sink terms. Laakso et al. (2006) quantified its relative contribution to less than $10 \%$. Despite these nontrivial theories, numerous discrepancies exist and so far none of these schemes is capable of adequately explaining the details of observed particle formation and growth rates in the boundary layer above vegetation. There is a need for modified or novel approaches and explanations for the growth of NIM to detectable sizes of $3 \mathrm{~nm}$ in particle diameter.

The remaining possibility to bridge this gap between nucleus formation at molecular sizes and the condensation/partitioning above sizes of about $5-10 \mathrm{~nm}$ in diameter is of reactive nature. Herein gas-phase molecules interact with cluster surfaces and form new macromolecules (Zappoli et al., 1999; McFiggans et al., 2004; Kalberer et al., 2004; O'Dowd and Hoffmann, 2005). The process is not affected by the Kelvin effect and is controlled only by the reactivity and concentration of cluster and corresponding molecules. This reaction-controlled activation (RCA) requires the presence of trace gases, possessing a high reactivity and notable molar mass, i.e. larger radicals, which basically initiate a catalytic reaction chain. In this RCA, radicals react with clusters maintaining the reactive functional group and contributing to particulate mass (Burkholder et al., 2004). Which resulting organic substances are to be expected is a subject of intensive discussion especially among the smog chamber experimentalists, who identified e.g. large dimers (Kalberer et al., 2004; Kristensen et al., 2014), and is a central aspect for this study. However the reactive mass increase of clusters and smallest particles seems to be in line with observations made so far. The process is similar to the behaviour of OIO that initiates a polymerisation to form new clusters and particles. The process itself is capable of explaining new particle formation observed at coastal sites (O'Dowd et al., 2001; McFiggans et al., 2004; O'Dowd and Hoffmann, 2005). But halogen radicals are not available in substantial amounts for nucleation at forest sites.

In forested areas large amounts of biogenic volatile organic compounds (BVOCs) are emitted (Guenther et al., 1995, 2006; Bourtsoukidis et al., 2012). These compounds have a variety of different reactivities, functionalities, molecular sizes (Kesselmeier and Staudt, 1999) and driving forces (Guenther et al., 1995; Niinemets et al., 2010; Bourtsoukidis et al., 2012). During daytime most of the BVOCs are 
oxidised by the hydroxyl radical $(\mathrm{OH})$ to form an organic peroxy radical $\left(\mathrm{RO}_{2}\right)$ in the first stage. This radical proceeds reacting with one of the other available radicals such as $\mathrm{HO}_{2}, \mathrm{NO}, \mathrm{RO}_{2}$ and $\mathrm{NO}_{3}$ in the gas-phase to form stable intermediate products such as alcohols, nitrates, organic hydroperoxides, carbonyl compounds or organic acids. Those compounds contribute to secondary organic aerosol mass after partitioning to the pre-existing organic aerosol (Pankow, 1994; Hoffmann et al., 1997; Barsanti and Pankow, 2004, 2005, 2006; Donahue et al., 2006, 2011). A further heterogeneous reaction was postulated by Bonn et al. (2007) and revealed under laboratory conditions by Wolf et al. (2009, 2011) for organic peroxy radicals consisting of more than five carbon atoms $\left(\mathrm{RO}_{2}(\mathrm{C}>5)\right)$. In this context Wolf et al. (2009) observed a rapid increase of $\mathrm{RO}_{2}$ mass production with increasing carbon numbers above five. These large organic peroxy radicals are thought to react with aerosol constituents producing a variety of different macromolecules that have been seen in infrared spectra (Wolf et al., 2009). The products such as esters, ethers and dimers are of fragile nature and undergo chemical transformations in the following. Some may have weak $\mathrm{O}-\mathrm{O}$ bonds that may crack easily at collisions, photolysis or heat transfer. Thus, a sampling technique relying on accumulating sufficient mass will have serious challenges to solve. These aspects are supported by the following observation of Wolf et al. (2009) that indicates the weak bonding strengths of the products formed: Wolf et al. (2009) could not see substantial mass gain by organic peroxy radicals with less than six carbon atoms. According to quantum chemical simulations the products are expected to split after formation of a very short-lived intermediate caused by the release of reaction energy, undergoing transfer to stable carbonyl compounds. Thus, the chemical nature of the nuclei becomes less reactive and does not grow in size. An effective nucleation process is evidently prevented. Organic peroxy radicals with six $\mathrm{C}$ atoms or more $\left(\mathrm{RO}_{2}(\mathrm{C}>5)\right)$ tend to distribute the elevated energy over a sufficiently large molecule and form a tentatively stable macromolecule. The difference in behaviour of small and large $\mathrm{RO}_{2}$ may result in a negative i.e. suppressive effect of isoprene-induced $\mathrm{RO}_{2}$, while a positive effect is to be expected from terpenoid-induced $\mathrm{RO}_{2}$ radicals. The proposed growth process is independent of the cluster chemical nature, i.e. inorganic or organic, and is only dependent on its reactivity with respect to ambient radicals. This distinction between small and large organic compounds has important implications for BVOC emissions from vegetation: temperate forests with high emissions of isoprene will yield small $(\mathrm{C} \leq 5) \mathrm{RO}_{2}$ in high amounts, preventing activation and thus particle formation (Kiendler-Scharr et al., 2009), while coniferous forests with dominant (mono)terpene emissions act as proposed by Bonn et al. (2007) and Wolf et al. (2009, 2011).

Support for this process has been found recently in laboratory studies (Hummel, 2010; Ebach, 2010; Kestel, 2013). These studies used alkene-ozone reactions in the presence of nopinone $\left(\mathrm{C}_{9} \mathrm{H}_{14} \mathrm{O}\right)$, a ketone product of ${ }_{\beta}$-pinene oxidation. Neither ethene- nor propene- or cis-2-butene-ozone reactions are expected to create new particles at moderate concentrations in the range of less than $10^{12} \mathrm{~cm}^{-3}\left(<40 \mathrm{ppb}_{\mathrm{v}}\right)$. However, adding nopinone $\left(2.5 \times 10^{12}-1.5 \times 10^{13} \mathrm{~cm}^{-3}\right.$, that is $100-1000 \mathrm{ppb}_{\mathrm{v}}$, i.e. ca. two to three orders of magnitude below saturation level), they cause significant formation of new particles and the activation process can be explained solely by the formed $\mathrm{OH}$ radicals as a product of the ozonolysis and the organic peroxy radicals involved.

For the present study three different nucleation hypotheses are considered:

A. sulfuric acid only based on Nieminen et al. (2012),

B. interaction of organic compounds with sulfuric acid based on Bonn et al. (2008) and Metzger et al. (2010) and

C. organic only based on studies of Bonn et al. (2007); Wolf et al. (2009, 2011); Hummel (2010); Ebach (2010) and Kestel (2013).

\section{1 (A) Sulfuric acid only}

This hypothesis is solely focused on the presence of sulfuric acid, obtained from fits to measurement data at the Finnish boreal station Hyytiälä and is scaled to the acid concentration as

$J_{3, \mathrm{H}_{2} \mathrm{SO}_{4}}=2 \times 10^{-11} \mathrm{~cm}^{-3} \mathrm{~s}^{-1}\left(\left[\mathrm{H}_{2} \mathrm{SO}_{4}\right] \mathrm{cm}^{3}\right)^{1.78}$.

The pre-factor $2 \times 10^{-11} \mathrm{~cm}^{-3} \mathrm{~s}^{-1}$ includes all unknowns and the reactivity of interacting, partially unknown compounds.

\section{2 (B) Interaction of organic compounds with sulfuric acid}

The nucleation is described empirically as a product of monoterpenes, $\mathrm{OH}$, condensation sink in the unit $\mathrm{s}^{-1}(\mathrm{CS}$, see Eq. 3) and sulfuric acid concentration assigned with a scaling factor $K$ (Kulmala et al., 2006; Sihto et al., 2006; Riipinen et al., 2007) and has been found to agree in a certain range for different ecosystems around the globe:

$J_{3, \operatorname{mix}}=K \cdot \frac{[\mathrm{MT}][\mathrm{OH}]}{\mathrm{CS}} \cdot\left[\mathrm{H}_{2} \mathrm{SO}_{4}\right]$.

This formation approach (Eq. 2) uses the sulfuric acid concentration, an empirical fitting parameter $K$ derived from ambient measurements and includes a monoterpene- $\mathrm{OH}$ oxidation product that is assumed non-volatile and sticks to any aerosol surface at collision. For the present study a fit of PARADE data results in a $K$ value of $(5 \pm 1) \times 10^{-25} \mathrm{~cm}^{6} \mathrm{~s}^{-2}$ that is used for the intercomparison. For the formation approach (B) the lifetime of smallest clusters is assumed as $1 / \mathrm{CS}$, i.e. the ambient lifetime before collision with the next 
particle surface. CS in $\mathrm{s}^{-1}$ is used as formulated by Pirjola and Kulmala (1998):

$$
\begin{aligned}
& \mathrm{CS}=2 \int_{D_{\mathrm{p} 0}}^{\infty} \beta n\left(D_{\mathrm{p}}\right) \beta_{M} \mathrm{~d} D_{\mathrm{p}} \\
& \approx 2 \pi D_{i} \sum_{i} \frac{1+\frac{2 \lambda_{\text {air }}}{D_{\mathrm{p}}}}{1+\left(0.377+\frac{3}{4 \alpha}\right) \cdot \frac{2 \lambda_{\text {air }}}{D_{\mathrm{p}}}+\frac{3}{4 \alpha}\left(\frac{2 \lambda_{\text {air }}}{D_{\mathrm{p}}}\right)^{2}} \cdot D_{\mathrm{p} i} N_{i} \\
& \mathrm{CS}^{\prime}=\frac{\mathrm{CS}}{4 \pi D_{i}} .
\end{aligned}
$$

These two equations include several parameters: the diffusion coefficient of the condensing molecules $D_{i}$ commonly assumed to be sulfuric acid, the collision rate $\beta$ of gas molecules and particles which changes for different sizes, the particle number density $n\left(D_{\mathrm{p}}\right)$, the transition correction factor $\beta_{M}$ for different particle sizes that includes the Knudsen number $K n\left(=\frac{2 \lambda_{\text {air }}}{D_{\mathrm{p}}}\right)$, the mean free path of air $\lambda_{\text {air }}$, the particle diameter $D_{\mathrm{p}}$, the sticking coefficient $\alpha$ commonly assumed to be 1 and finally the particle number concentration $N_{i}$ in a certain size section $i$. In order to calculate the entire loss of condensing molecules the loss must be integrated over the entire particle size distribution with the largest particles contributing most because of the difference in speed and because of the large surface area.

Analysing the particle formation rate description in Eq. (2), it may be concluded that the proposed interaction of large $(C>5)$ organic peroxy radicals is already included. Those are formed in the first step of monoterpene oxidation by $\mathrm{OH}$. The reciprocal condensation sink displays a lifetime that is in the same range as the common $\mathrm{RO}_{2}$ sinks such as $\mathrm{NO}$ or the hydroperoxy radical $\mathrm{HO}_{2}$. The $K$ factor can be interpreted as well in two different ways, i.e. as described by Bonn et al. (2008) as a lumped constant from several reactions including ozone, terpenes and water vapour or as the reaction rate constant between organic peroxy radicals from monoterpenes and $\mathrm{OH}$ times the former reaction rate constant of the monoterpene- $\mathrm{OH}$ product and sulfuric acid.

\section{3 (C) Organic only}

This new particle formation theory is described by a threestep process (see Fig. 1): (1) first the nucleation initiating molecule (NIM) with weak chemical bonds such as the secondary ozonide (SOZ) is formed (Bonn et al., 2002; Bonn and Moortgat, 2003). It provides insufficient supersaturation to allow homogeneous nucleation to occur. (2) The activation step occurs essentially as a catalytic chain reaction including the large organic peroxy radicals $\left(\mathrm{RO}_{2}(\mathrm{C}>5)\right)$ as well as stabilised Criegee intermediates (sCI, Criegee (1975)), during which the weak $\mathrm{O}-\mathrm{O}$ bond is continuously split and reformed. This process is supposed to bridge the gap between the NIM size of around $1 \mathrm{~nm}$ and the step 3. (3) Onset of partitioning of organic compounds (Pankow, 1994). In

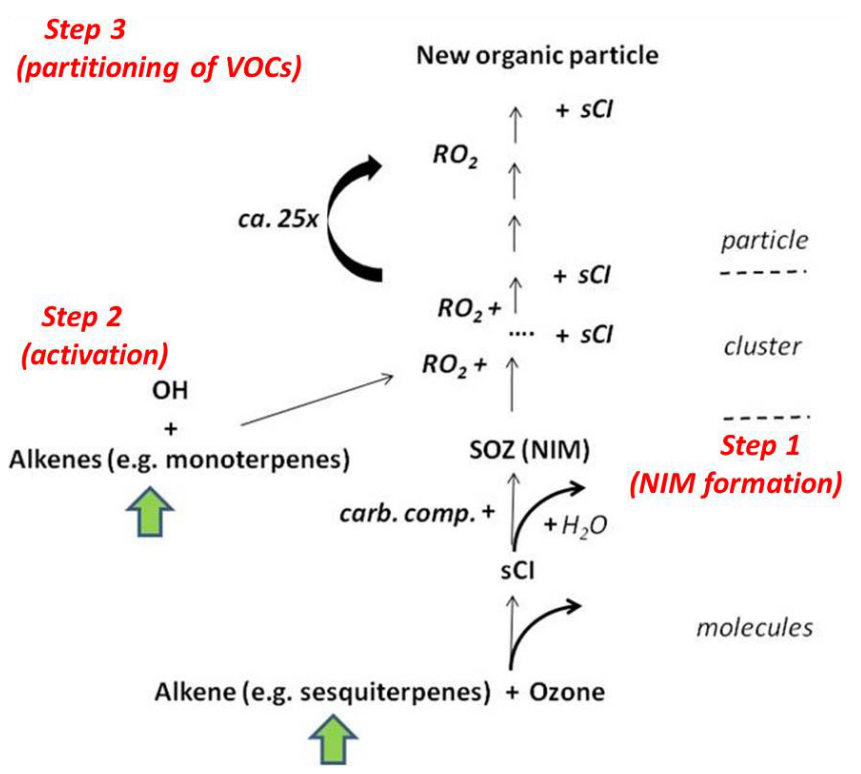

Figure 1. Particle formation scheme of hypothesis (C) by organic compounds only. Three essential steps, of which the first two can both limit nucleation, are marked.

terms of mass production, this step becomes efficient above about $5 \mathrm{~nm}$ and dominant above about $10 \mathrm{~nm}$ in particle diameter. This third step actually includes the partitioning and the condensation of low volatile compounds and heterogeneous reactions such as acid-catalysed reactions (Barsanti and Pankow, 2004, 2005, 2006).

The formation rate $J_{3}$ can be summarised by the Eqs. (5) and (6). It approximates the formation process by the limiting reaction between the $\mathrm{SOZ}$ and either a $\left(\mathrm{RO}_{2}(\mathrm{C}>5)\right)$ or a sCI. For this purpose $\mathrm{SOZ},\left(\mathrm{RO}_{2}(\mathrm{C}>5)\right)$ and $\mathrm{sCI}$ are gained by steady-state approaches (i.e. sources balance sinks), which is feasible for short-lived gases in the ambient with respect to the time resolution. However, for the SOZ this may result in a moderate overestimation because of its larger lifetime of several minutes up to a quarter of an hour. The empirically shortened formulation results from a set of laboratory studies (Bonn et al., 2002; Bonn and Moortgat, 2003; Hummel, 2010; Ebach, 2010; Kestel, 2013) conducted earlier on the impact of a variety of trace gases such as $\mathrm{NO}, \mathrm{CO}$, water vapour and large ketones:

$$
\begin{aligned}
& J_{3, \text { org }}=[\mathrm{SOZ}] \cdot \min \left(2.5 \times 10^{-13} \mathrm{~cm}^{3} \mathrm{molec}^{-1} \mathrm{~s}^{-1}\right. \\
& \left.\cdot\left[\mathrm{RO}_{2}\right](\text { terp. }), 2 \times 10^{-12} \mathrm{~cm}^{3} \mathrm{molec}^{-1} \mathrm{~s}^{-1} \cdot[\mathrm{sCl}]\right) \\
& . \frac{2.5 \times 10^{-13} \mathrm{~cm}^{3} \mathrm{molec}^{-1} \mathrm{~s}^{-1} \cdot\left[\mathrm{RO}_{2}\right](\text { terp. })+2 \times 10^{-12} \mathrm{~cm}^{3} \mathrm{molec}^{-1} \mathrm{~s}^{-1} \cdot[\mathrm{sCl}]}{k_{\mathrm{RO}_{2}}^{\mathrm{RO}_{2}}\left[\mathrm{HO}_{2}\right]+k_{\mathrm{RO}_{2}}^{\mathrm{NO}_{2}}[\mathrm{NO}]+k_{\mathrm{RO}_{2}}^{\mathrm{NO}_{3}}\left[\mathrm{NO}_{3}\right]+k_{\mathrm{RO}_{2}}^{\mathrm{RO}_{2}}\left[\mathrm{RO}_{2}\right]} \\
& \mathrm{SOZ}=\frac{k_{\mathrm{SQT}}^{\mathrm{O}_{3}}[\mathrm{SQT}]\left[\mathrm{O}_{3}\right] \cdot Y_{\mathrm{stab}}}{80 \mathrm{~s}^{-1}+k_{\mathrm{SCI}}^{\mathrm{H}_{2} \mathrm{O}}\left[\mathrm{H}_{2} \mathrm{O}\right]} \cdot \frac{80 \mathrm{~s}^{-1}}{k_{\mathrm{SOZ}}^{\mathrm{OH}}[\mathrm{OH}]+\mathrm{CS}}
\end{aligned}
$$

where [SOZ] is the secondary ozonide concentration formed by the intramolecular formation during sesquiterpene (SQT) 
ozone $\left(\mathrm{O}_{3}\right)$ reactions as approximated in Eq. (6). The kinetic speed of this intramolecular reaction has been quantified by Beck et al. (2011) for $\alpha$-humulene and was assumed identical for $\beta$-caryophyllene, farnesene and the other sesquiterpenes present at Taunus Observatory (Bourtsoukidis et al., 2012). The reaction rate constant of the stabilised Criegee intermediates (sCI) with water, which is currently not accurately determined $\left(10^{-19} \mathrm{~cm}^{-3} \mathrm{~s}^{-1}<\right.$ $k_{\mathrm{sCl}}^{\mathrm{H}_{2} \mathrm{O}}<10^{-15} \mathrm{~cm}^{-3} \mathrm{~s}^{-1}$, Atkinson et al., 2006), is assumed as $2 \times 10^{-17} \mathrm{~cm}^{3} \mathrm{~s}^{-1}$ (Großmann, 1999) and $Y_{\text {stab }}$ is the stabilisation ratio of the sesquiterpene mixture (here: assumed as 0.8 ). $\mathrm{RO}_{2}$ (terp.) represents the sum of organic peroxy radicals formed from (mono)terpene oxidation by $\mathrm{OH}$ and $\mathrm{NO}_{3}$. It is important to note that while the sesquiterpenes are assumed to contribute primarily to the $\mathrm{SOZ}$ formation, monoterpenes and oxidation products are considered to control the activation process by $\mathrm{sCI}$ and $\mathrm{RO}_{2}$ (terp.). Although monoterpenes react much more slowly with ambient ozone, their sCIs do not form SOZ intramolecularly and therefore the concentration is essentially dependent on the primary sink reaction with ambient water vapour.

The mean reaction rate $k_{\mathrm{SOT}}^{\mathrm{O}_{3}}$ of the sesquiterpene mixture (Bourtsoukidis et al., 2012) with ambient ozone was calculated from the product of individual contributions and reaction rate constants taken as available from the literature. Missing reaction rate constants for individual SQTs have been approximated by structure activity relationships (I. Kourtchev, personal communication, 2012) based on the detected mixture determined by GC-MS analysis. The value of 1/CS again represents the approximated lifetime of SOZ molecules before being lost to an aerosol surface, which is controlled by pre-existing aerosol surface area. The chemical destruction of $\mathrm{SOZ}$ is assumed to occur by $\mathrm{OH}\left(k_{\mathrm{SOZ}}^{\mathrm{OH}}=\right.$ $7.29 \times 10^{-11} \mathrm{~cm}^{3} \mathrm{~s}^{-1}$ ) (Saunders et al., 2003; Jenkin et al., 2003), which leads to a minimum chemical lifetime of about $10^{4} \mathrm{~s}$ assuming a hydroxyl radical concentration $[\mathrm{OH}]$ of $10^{6} \mathrm{~cm}^{-3}$. If compared to the sink on aerosol surfaces (CS) the destruction by $\mathrm{OH}$ contributes negligibly to the gas-phase loss of SOZ. Finally, the minimum expression of two reaction rates of $\mathrm{RO}_{2}(\mathrm{C}>5)$ and of $\mathrm{sCI}$ with the $\mathrm{SOZ}$ or the cluster, respectively, represents the activation step (2) with the slower one controlling the entire process. These two reaction rate constants are taken from laboratory experiments of Hummel (2010) and simulations of Ebach (2010) representing the activation cycle summarised in a single step. While the reaction rate constant of $\mathrm{RO}_{2}$ and NIM is basically the $\mathrm{RO}_{2}+\mathrm{RO}_{2}$ reaction rate constant for larger peroxy radicals (Atkinson et al., 2006), the reaction rate constant of sCI and NIM is about $1.5 \times 10^{5}$ times the one of SCI with water. This was found to be rather consistent for a range of different conditions.

At least two of the nucleation hypotheses (B) and (C) are linked to organic peroxy radicals, while the situation remains

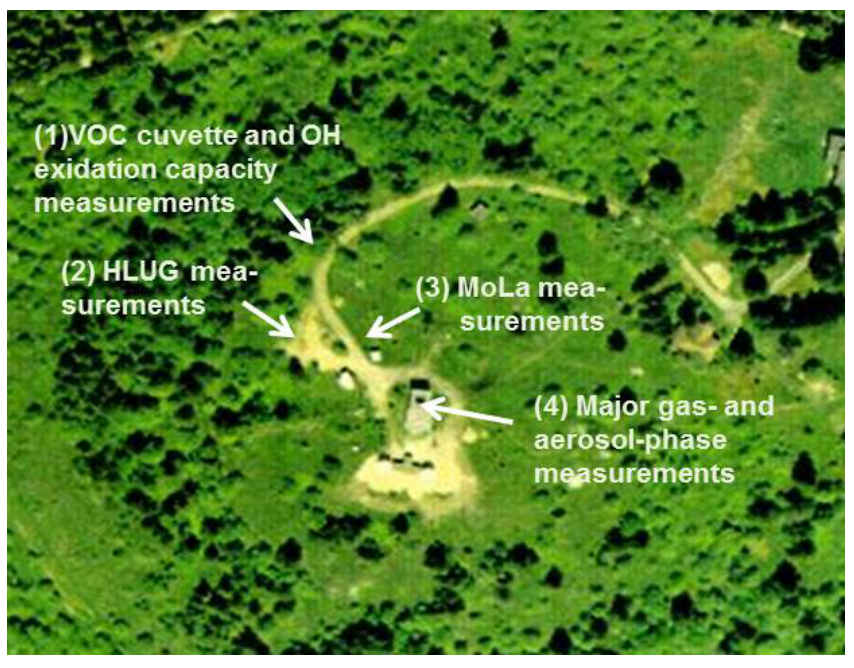

Figure 2. Campaign site and locations of individual measurements.

unclear in case (A) because of the lumping of a multitude of processes in a single empirical fitting constant.

In order to test this hypothesised link between radicals and particle formation rates and to evaluate the potential importance of the individual pathways for atmospheric conditions at Mt Kleiner Feldberg, we require the knowledge of the concentrations of individual terpene groups, $\mathrm{OH}, \mathrm{NO}_{3}$, ozone, water vapour, large organic peroxy radicals $\left(\mathrm{RO}_{2}(\mathrm{C}>5)\right)$, $\mathrm{HO}_{2}$, NO, stabilised Criegee intermediates (sCI) and of the condensation sink CS of NIM at approximately $1.2-1.5 \mathrm{~nm}$.

\section{Measurements and methods}

The "Particles And RAdicals: Diel observations of the impact of urban and biogenic Emissions" (PARADE) campaign measurements were conducted at Taunus Observatory $\left(50^{\circ} 13^{\prime} \mathrm{N}, 8^{\circ} 26^{\prime} \mathrm{E}, 825 \mathrm{~m}\right.$ a.s.l. $)$. It is located at the hilltop of the second highest elevation of the Taunus ridge within a managed spruce forest of about 60 to $80 \mathrm{yr}$ in age (Handisides et al., 2003). While the forest predominantly consists of spruce, smaller amounts of pines are present. The hill top was cleared of any forests about a century ago for meteorological measurements (circle of around $160 \mathrm{~m}$ in diameter) and kept free of coniferous trees since then. Several invasive smaller trees or bushes have grown there since then. A full set of trace gas, radical, particle and photolysis measurements were performed between 14 August and 9 September 2011.

\subsection{Gaseous measurements}

Gas-phase measurements were performed at two different locations (Fig. 2) due to the campaign focus and the measurement capacities:

a. at the hill top including the following compounds were measured: ozone, $\mathrm{NO}, \mathrm{NO}_{2}, \mathrm{NO}_{3}, \mathrm{~N}_{2} \mathrm{O}_{5}$, PAN, $\mathrm{HONO}$, 
$\mathrm{CO}, \mathrm{HO}_{2}, \mathrm{H}_{2} \mathrm{O}_{2}, \mathrm{SO}_{2}, \mathrm{H}_{2} \mathrm{SO}_{4}, \mathrm{HCHO}$, glyoxal, acetone, methanol, toluene and monoterpenes.

b. The second point was located close to the forest (for further details see Bourtsoukidis et al., 2012) measuring at a dynamical plant cuvette, which allowed detection of the ambient mixing ratio when a budget approach was applied. The compounds investigated were $\mathrm{HCHO}$, acetone, benzene, isoprene, mono- and sesquiterpenes, major primary terpene oxidation products such as nopinone and pinonaldehyde and linalool. A highly time-resolved measurement of volatile organic compound (VOC) pattern was obtained continuously by a high-sensitivity Proton Transfer Reaction-Mass Spectrometry (PTR-MS, Ionicon, Bourtsoukidis et al., 2014) with a lower detection limit of $1 \mathrm{ppt}_{\mathrm{v}}$ at proper sampling time in a plant cuvette at $4 \mathrm{~m}$ above soil level at a sunlit branch at the edge of the forest. This was essential to obtain sesquiterpene emissions and ambient mixing ratios above the detection limit. More details on the method can be found in Bourtsoukidis et al. (2012, 2014). Because of the insensitive PTR-MS approach for compounds with identical molar masses the detailed composition of mono- and sesquiterpenes were derived by (a) exemplary branch samples analysed by gas chromatography-mass spectrometry (GCMS) (FMI, Helsinki, FI) (Hakola et al., 2006) during the season and (b) by air samples analysed by GC-MS (MPI Mainz). OH reactivity was obtained by a novel method from the Max-Planck Institute in Mainz (Nölscher et al., 2012, 2013) for the same cuvette as used for the VOC measurements using the PTR-MS and at the hill top too. The individual instruments and methods as well as the corresponding groups responsible for data acquisition are listed in Table 1.

\subsection{Particle measurements}

Particles were measured by different sets of instruments. One set measured the particle size distribution by a nano-DMPS (Grimm) set-up focusing on the smallest particle size range between 3 and $20 \mathrm{~nm}$ in particle diameter at the hill top container. This nano-DMPS was operated with calibrated flow rates and central electrodes. According to the manufacturer Grimm the nano-DMA (Grimm) operates down to $2 \mathrm{~nm}$ with high accuracy. In order to detect particles down to $1.5 \mathrm{~nm}$ in diameter a Booster-condensation particle counter (first step: DEG condensation, second step: buthanol condensation with a final particle diameter of approximately $10 \mu \mathrm{m}$ in particle diameter) was applied. Assuming the charged fraction to proceed towards smaller sizes as established for larger ones (Wiedensohler and Fissan, 1988), three different corrections were performed, which base of the constrainment of flows, charge ratios of the particles and electrical fields: (i) charging probability correction based on the Americium source ac- cording to Wiedensohler and Fissan (1988), (ii) DMA transfer function including diffusional broadening according to Stolzenburg and McMurry (2008) and (iii) diffusion losses at the inlet and outlet according to Karlsson and Martinsson (2003) by application of the effective length concept (Jiang et al., 2011). Because of the extremely short inlet pipe compared to the effective length of $3.87 \mathrm{~m}$ (Jiang et al., 2011), any further losses were expected to be negligible and have not been considered. Particle formation rates $J_{3}$ at $3 \mathrm{~nm}$ were considered as the positive change in concentration of the particles between 3 and $5 \mathrm{~nm}$ per $10 \mathrm{~min}$ interval. For condensation sink calculations a second set-up, a FMPS and an OPC were deployed in a Mobile Laboratory (MoLa) (Drewnick et al., 2012) about $20 \mathrm{~m}$ away from the cuvette measurement site in the eastward direction (Fig. 2). With this set-up, particle size distributions between $5.6 \mathrm{~nm}$ and $32 \mu \mathrm{m}$ were detected, which is sufficient for aerosol sink estimates. The condensation sink itself was calculated according to Pirjola and Kulmala (1998) and Kulmala et al. (2001) as given in Eq. (3). All particle measurements were conducted at a height of about 5 to $6 \mathrm{~m}$ above soil level similar to gas-phase and wind speed measurements. The detailed instrumentation and references to their methods can be found in Table 1 .

\subsection{Boundary layer mixing and dilution}

As the hill top site is not homogeneous, with the surrounding vegetation diverse in height, mixture and density, a distinct horizontal variation of the individual parameters, especially of VOCs and related radicals, has to be expected. Therefore we will describe how forest edge concentration measurements have been modified to account for dilution during advection to the aerosol measurement location at the hill top centre. This step is necessary in order to allow intercomparison with the aerosol measurements and the calculations based on the different hypotheses (A)-(C). It is important to remember the different locations of the measurements due to optimum measurement conditions. VOC measurements were conducted at the spruce forest edge, while most of the other measurements were performed at the hill top at a distance between 20-60 $\mathrm{m}$ away from the forest edge (Sect. 3.1). Therefore the derived VOC concentrations need a dilution correction as a function of wind speed and direction as well as of boundary layer characteristics to obtain the concentration at the aerosol measurement location.

This was done using the numerical atmospheric boundary layer model SCADIS applied to a very detailed 3-D structure of the present surface. The model accounts for topographic variations and considers the vegetation as a multi-layer medium. Implementing parameterisations for drag forces on leaves and stomatal conductance enables SCADIS to describe the exchange between the vegetative canopy and the atmosphere. The full description of the model, equations, and numerical details can be found in Sogachev et al. (2002, 2004, 2012). Spatial resolution was set to $5 \mathrm{~m}$ and the model 
Table 1. Measured parameter, instrumentation and groups responsible during the campaign.

\begin{tabular}{|c|c|c|}
\hline Measured parameter & Instrumental techn. and instrument & Group responsible \\
\hline $\mathrm{O}_{3}$ & UV absorption, TE49 & Fischer, MPI Mainz, D \\
\hline $\mathrm{NO}, \mathrm{NO}_{2}$ & chemiluminescence, & Fischer, MPI Mainz, D \\
\hline $\mathrm{CO}$ & RT-QCLS, & Fischer, MPI Mainz, D \\
\hline $\mathrm{H}_{2} \mathrm{O}_{2}$ & Dual enzyme method, AL 2021 & Fischer, MPI Mainz, D \\
\hline $\mathrm{HCHO}$ & Hantzsch method, AL 4021 & Fischer, MPI Mainz, D \\
\hline $\mathrm{NO}_{2}$ & GANDALF (LIF-NO2) & Harder, MPI Mainz, D \\
\hline $\mathrm{OH}, \mathrm{HO}_{2}$ & IPI-FAGE-LIF & Harder, MPI Mainz, D \\
\hline PAN, PAA & Iodide CIMS & Crowley, MPI Mainz, D \\
\hline $\mathrm{NO}_{3}, \mathrm{~N}_{2} \mathrm{O}_{5}$ & CRD & Crowley, MPI Mainz, D \\
\hline $\mathrm{NO}_{2}$, alkylnitrates & TD-CRDS & Crowley, MPI Mainz, D \\
\hline Methanol, toluene & PTR-ToF-MS & Koppmann, BU Wuppertal, D \\
\hline $\begin{array}{l}\text { Isoprene, terpenes, } \\
\text { div. VOCs }\end{array}$ & PTR-MS, Ionicon, AUT & Bonn, GU Frankfurt/M., D \\
\hline $\begin{array}{l}\text { Ind. terpene } \\
\text { quantification }\end{array}$ & GC-MS & Hakola, FMI, Helsinki, D \\
\hline $\mathrm{OH}$ reactivity & PTR-MS & Williams, MPI Mainz, D \\
\hline $\mathrm{H}_{2} \mathrm{SO}_{4}$ & CIMS & Curtius, GU Frankfurt/M., D \\
\hline$J_{5}$ & WCPC (TSI 3785) & Bingemer, GU Frankfurt/M., D \\
\hline $\begin{array}{l}\text { Aerosol size } \\
\text { distribution }\end{array}$ & FMPS, APS & Drewnick, MPI Mainz, D \\
\hline $\begin{array}{l}\text { Particle size distribution } \\
(3-20 \mathrm{~nm})\end{array}$ & nano-SMPS & Kürten, GU Frankfurt/M., D \\
\hline Photolysis rates & CCD spectrometer & Bohn, FZ Jülich, D \\
\hline HONO & LOPAP & Li, FZ Jülich, D \\
\hline $\begin{array}{l}T, \mathrm{RH}, \mathrm{O}_{3}, \\
\text { global radiation, } \mathrm{NO}_{\mathrm{x}}\end{array}$ & div. & Jacobi, HLUG, Wiesbaden, D \\
\hline
\end{tabular}

Table 2. Relative dilution at standard wind speed for four different wind directions between the hill top and the closed forest edge opposite to wind direction.

\begin{tabular}{lll}
\hline Wind direction & $\begin{array}{l}\text { Relative reduction } \\
\text { (nano-DMPS, gases) }\end{array}$ & $\begin{array}{l}\text { Relative reduction } \\
\text { (FMPS, OPS) }\end{array}$ \\
\hline Southward $\left(0^{\circ}\right)$ & $-(5 \pm 1) \%$ & $-(0 \pm 1) \%$ \\
Westward $\left(90^{\circ}\right)$ & $-(5 \pm 1) \%$ & $-(25 \pm 5) \%$ \\
Northward $\left(180^{\circ}\right)$ & $-(50 \pm 5) \%$ & $-(65 \pm 5) \%$ \\
Eastward $\left(270^{\circ}\right)$ & $-(50 \pm 5) \%$ & $-(65 \pm 5) \%$ \\
\hline
\end{tabular}

was initialised with the ALKIS data set of the Hessian local agency for surface management and geoinformation (HVBG, Wiesbaden, Germany). With sources of passive scalar prescribed according to Sogachev et al. (2008), concentration fields around and over the forest gap were calculated. Therefore a vegetation-mass-related emission was assumed for an unreactive compound in the three dimensional space. Implementing neutrally stratified conditions allows us to assume a similarity of modelled airflow and concentration fields in the range of observed wind speeds. For each wind direction the reduction due to dilution was calculated for a standard wind profile (see e.g. Fig. 3). This considers a mean horizontal wind velocity of $u_{\text {stand }}$ of $2 \mathrm{~m} \mathrm{~s}^{-1}$ at the measurement container of the Hessian Agency for Environment and Geology (HLUG, Wiesbaden, Germany) that is half of the way between forest and hill top measurement location. All wind velocities were subsequently normalised to the value at the forest edge. To estimate VOC mixing ratios at the hill top, the following procedure was applied:

a. Calculation of ambient mixing ratios at the forest edge [VOC] (forest edge) based on cuvette measurement budgets (Bourtsoukidis et al., 2014).

b. Calculation of the total dilution for each of the wind directions at standard wind speed conditions (Table 2) and linear interpolation in between.

c. Calculation of the transport time $\tau$ between the closest forest edge opposite to the wind direction (i.e. towards the west for an eastward wind), and derivation of dilution constant per time $\left(k_{\text {dil }}\right.$ (wind dir.)) using the calculated wind speed pattern and the distance iteratively.

d. Calculation of the summed losses of individual VOCs at measured wind speeds $u_{\text {meas }}$ and ozone concentrations (measurements at hill top applied): 
Topography

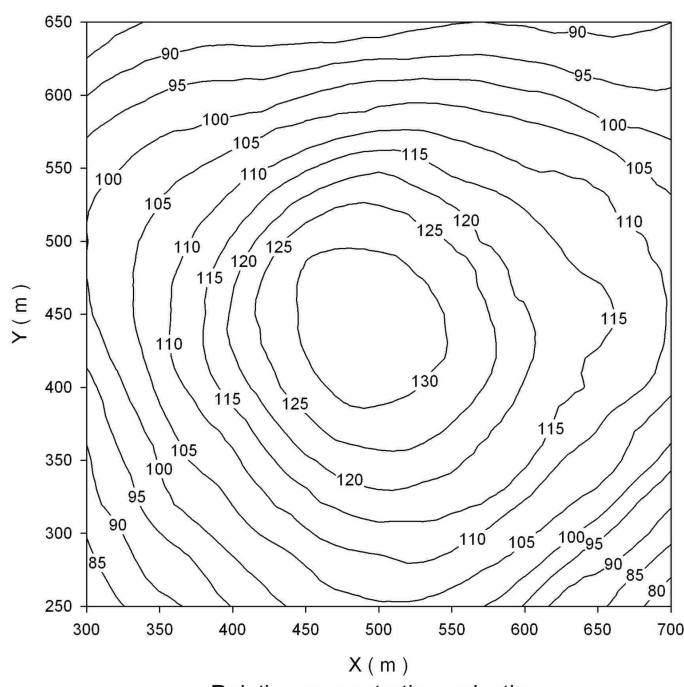

Relative concentration reduction

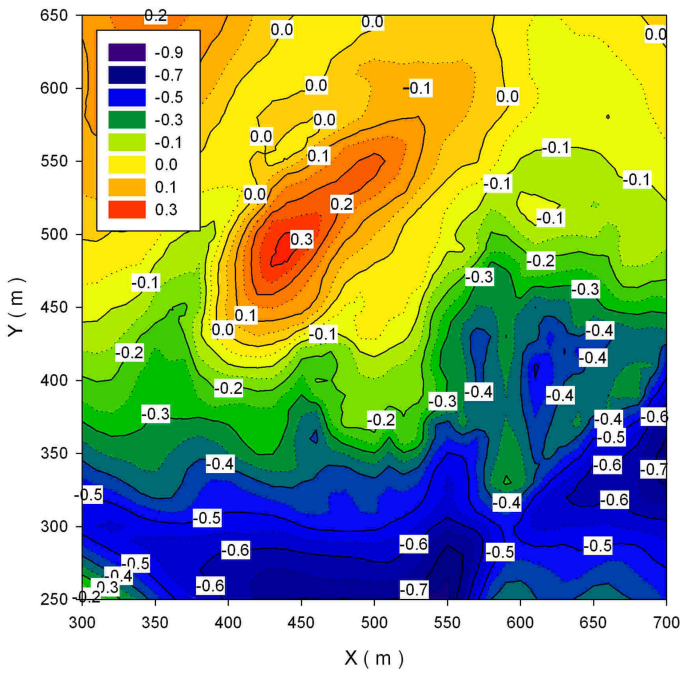

Lai

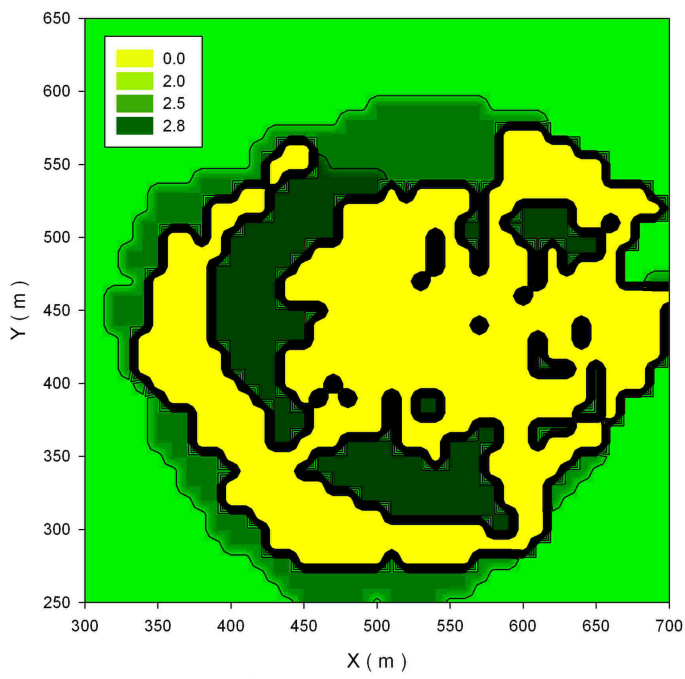

Relative flux reduction

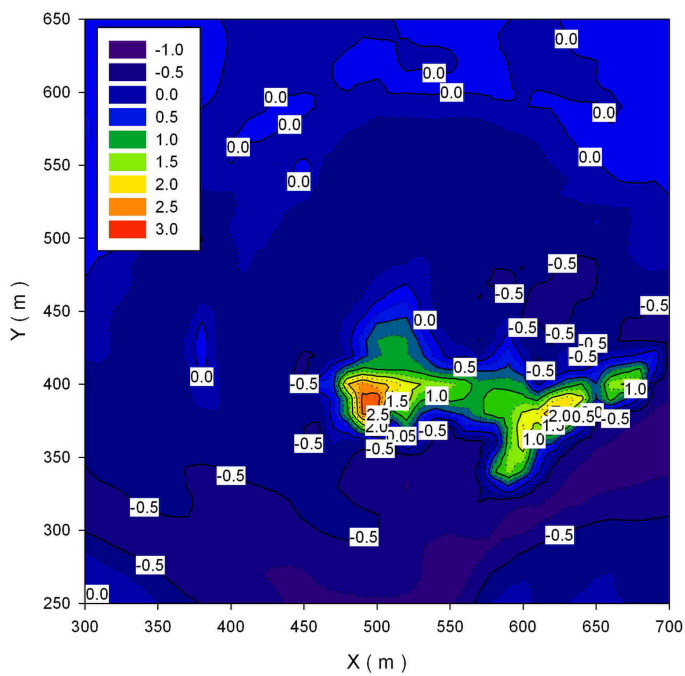

Figure 3. Exemplary relative dilution simulation of a passive scalar at the height of $4 \mathrm{~m}$ for a southward wind direction $\left(0^{\circ}\right)$. The figures display: (top, left) the topography, (top right) the leaf area index distribution, (bottom left) concentration difference scaled to the concentration at the forest edge and (bottom right) relative trace gas flux reduction (Eq. 4, see Fig. 2). The measurement container for gases and some aerosol parameters at the hill top is located at $(480 \mathrm{~m}, 430 \mathrm{~m})$. Further plots can be found in Supplement.

$[\mathrm{VOC}]($ hill top $)=[\mathrm{VOC}]($ forest $) \cdot$

$\exp \left(-\left(k_{\mathrm{dil}}+k_{\mathrm{VOC}}^{\mathrm{O}_{3}} \cdot\left[\mathrm{O}_{3}\right]\right) \tau \cdot \frac{u_{\text {meas }}}{u_{\text {stand }}}\right)$.

The wind speed $u_{\text {meas }}$ was obtained by HLUG at $4 \mathrm{~m}$ above the surface, half way between the forest edge and hill top, and was interpolated for $10 \mathrm{~min}$ intervals.

\subsection{Estimation of $\mathrm{OH}$ concentration}

One of the essential points for atmospheric particle formation is the quantification of atmospheric radicals such as $\mathrm{OH}$. Therefore different approaches were used: as planned $\mathrm{OH}$ measurements failed because of a detector malfunction, the following calculation methods were applied: (1) the correlation of the photolysis rate of $\mathrm{O}\left({ }^{1} \mathrm{D}\right) J\left(\mathrm{O}^{1} \mathrm{D}\right)$ with $\mathrm{OH}$ (Rohrer and Berresheim, 2006), (2) the budget approach of sources and sinks of $\mathrm{OH}$ as quantified by gaseous measurements and (3) the budget approach using quantified sources and $\mathrm{OH}$ reactivity measurements at the hill top.

With respect to approach $(1) J\left(\mathrm{O}^{1} \mathrm{D}\right)$ was measured by spectroradiometer as described by Bohn et al. (2008). Data were available during the entire period for daytime. Rohrer and Berresheim (2006) have found a linear correlation with a mean slope of $2.4 \times 10^{11} \mathrm{~s}$ for Hohenpeißenberg, Southern Germany. Available values for different comparable areas 
and pollution impacts were found between $1.4 \times$ and $3.9 \times$ $10^{11} \mathrm{~s}$, this range is also to be expected at the Taunus Observatory. As the site of interest is influenced by anthropogenic and biogenic sources neither of the assumptions of Rohrer and Berresheim (2006) is valid and the provided equations were used in an extensive version (see Supplement). With this, a correlation of $(1.8 \pm 0.1) \times 10^{11} \mathrm{~s}$ was found (see Supplement Fig. S8). This was used for photolysis rates above $10^{-6} \mathrm{~s}^{-1}$. Since this approach uses a limited amount of data and includes a notable uncertainty of individual parameters we assume a maximum uncertainty of the estimated $\mathrm{OH}$ concentration of a factor of 2 . For the budget approaches (approaches 2 and 3) a chemical box model has been used assuming a steady-state condition between all source and sink terms for $\mathrm{OH}$. All significant tropospheric production terms were considered, which include the photolysis of ozone in the presence of water vapour, hydrogen peroxide, HONO, $\mathrm{HNO}_{3}$ and the reactions of $\mathrm{HO}_{2}$ with $\mathrm{NO}$, ozone, and the nitrate radical. $\mathrm{HO}_{2}$ was estimated in a similar interactive way as $\mathrm{OH}$ through applying a chemical box model including the established tropospheric background chemistry (see the Master Chemical Mechanism v3.2, Saunders et al., 2003; Jenkin et al., 1997, 2003, 2012). Therefore initial $\mathrm{OH}$ and $\mathrm{HO}_{2}$ concentrations were assumed as follows: $10^{4} \mathrm{~cm}^{-3}$ for $\mathrm{OH}$ and $10^{7} \mathrm{~cm}^{-3}$ for $\mathrm{HO}_{2}$ and iterated 100 times until steadystate conditions were obtained. The $\mathrm{OH}$ destruction (sink) was taken into account by two different approaches, i.e. (approach 2) by considering all known sink terms of the radical (list of sinks, Supplement Table S1, section (B) and (approach 3 ) by taking into account the local $\mathrm{OH}$ reactivity measurements (Nölscher et al., 2013).

Intercomparison of the three different approaches (Fig. 4) yielded similar results. While approach (2) underestimated the $\mathrm{OH}$ concentration calculated by approach (1) during daytime (median: $-37 \%$ ), approach (3) overestimated it (median: $+39 \%$, values above $10^{7} \mathrm{~cm}^{-3}$ are excluded). This difference is caused by the different sink terms only. However, the sink calculated is notably larger $(+53 \%)$ than measured by the $\mathrm{OH}$ reactivity method of Nölscher et al. (2013) leading to higher $\mathrm{OH}$ estimations using the reactivity method. Most likely horizontal changes in VOC mixing ratios and further sinks do matter significantly as the $\mathrm{OH}$ reactivity changes notably from the forest edge towards the cleared hill cap. However, further investigations are beyond the scope of this study. More information can be found in the Supplement (Sects. B and C).

For formation rate calculations the measurements have been used where available and the estimations using approach $(1)\left([\mathrm{OH}]=f\left(J\left(\mathrm{O}^{1} \mathrm{D}\right)\right)\right)$ at daytime and the budget approach (2) at night-time, where $J\left(\mathrm{O}^{1} \mathrm{D}\right)$ is not available.

\subsection{Particle formation rate at $3 \mathrm{~nm}$ and $5 \mathrm{~nm}$}

In order to test the effect of different sizes, particle formation rates have additionally been calculated for $5 \mathrm{~nm}$ in diameter

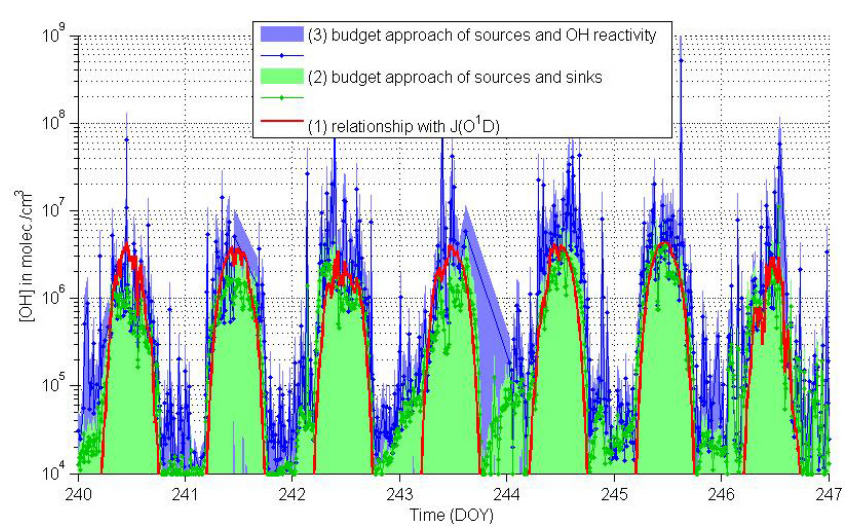

Figure 4. Concentrations of ambient $\mathrm{OH}$ calculated through different approaches for a period during PARADE (DOY 240-247): (1) $J\left(\mathrm{O}^{1} \mathrm{D}\right)$-based formulation, (2) budget approach of measured individual sources and sinks as well as (3) budget approach of measured individual sources and $\mathrm{OH}$ reactivity. The extended version can be found in the Supplement (Sect. B, Fig. S6, p. 10).

using the same nano-DMPS set-up. Both particle formation rates, i.e. at 3 and at $5 \mathrm{~nm}$ are related by the growth rate and the loss rate. As this is a purely dynamical process Kerminen and Kulmala (2002) have derived a simplified equation:

$$
\begin{aligned}
& J_{5}=J_{3} \cdot \exp \left(\gamma \frac{\operatorname{CoagS}^{\prime}(3 \mathrm{~nm})}{\mathrm{GR}} \cdot\left(\frac{1}{5 \mathrm{~nm}}-\frac{1}{3 \mathrm{~nm}}\right)\right) \operatorname{CoagS}^{\prime}(3 \mathrm{~nm}) \\
& =\frac{\operatorname{CoagS}(3 \mathrm{~nm})}{4 \pi D_{i}}
\end{aligned}
$$

Here $J_{3}$ and $J_{5}$ represent the formation rates at 3 and $5 \mathrm{~nm}$, $\gamma$ is a lumped factor of $0.23 \mathrm{~nm}^{2} \mathrm{~m}^{2} \mathrm{~h}^{-1}$ derived from diffusive speeds, and $\operatorname{CoagS}^{\prime}(3 \mathrm{~nm})$ is the coagulation sink of $3 \mathrm{~nm}$ particles (unit s ${ }^{-1}, \operatorname{CoagS}(3 \mathrm{~nm})$ divided by $4 \pi$ and the diffusion constant $D_{i}$ of the growing cluster). In the case of gases CoagS $S^{\prime}$ is replaced by $\mathrm{CS}^{\prime}$ and $D_{i}$ is the diffusion constant of the condensing species, here to be assumed as sulfuric acid as is commonly assumed (Kulmala et al., 2001).

The CoagS $S^{\prime}$ value in the unit of $\mathrm{m}^{2}$ (Kulmala et al., 2001; Dal Maso et al., 2005) has been calculated from the FMPSand OPC-derived particle size distribution. The GR at such small sizes is difficult to access directly especially above an inhomogeneous surface. For this a novel approach was applied. It is commonly assumed that new particle formation is linked to a rise in sulfuric acid concentration (Riipinen et al., 2007; Sihto et al., 2006) and thus in $\mathrm{OH}$ concentration or vice versa. The time difference in sulfuric acid or $\mathrm{OH}$ rise and the rise in particle number at a certain size can thus be interpreted as growing time. Thus the GR results from the size difference divided by the time shift. Here we cross-correlated the particle formation rate at $3 \mathrm{~nm} J_{3}$ with the $\mathrm{OH}$ concentration (measurement, or estimation where not available) and looked for the time of maximum correlation within five hours of a particular day $\left(\mathrm{GR}_{\min }=0.5 \mathrm{~nm} \mathrm{~h}^{-1}\right.$ assumed $)$. This limitation is set because of a limit in data at larger times. The 


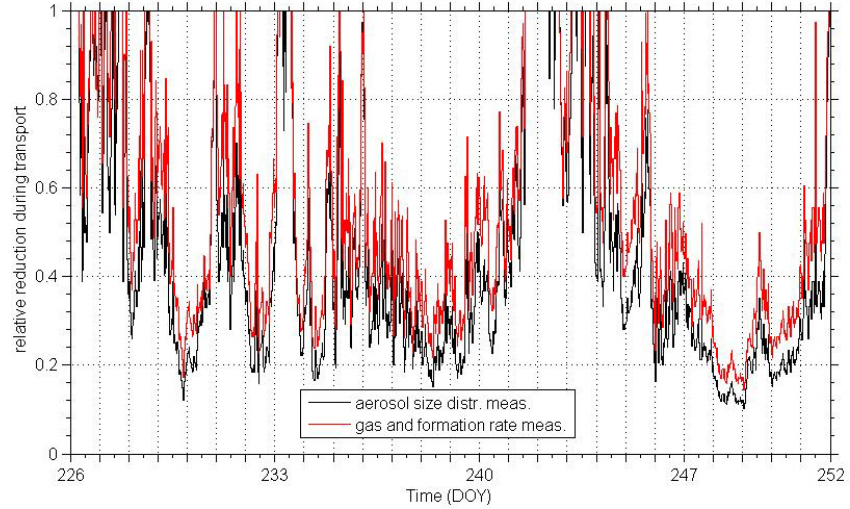

Figure 5. Relative reduction of concentrations during transport from the forest edge to the hill top depending on the present wind direction and speed. This factor is used for scaling the measured VOC concentrations to obtain values after transport.

cross-correlation displays the time shift between both quantities that displays the highest correlation. The application of the Kerminen-Kulmala (Kerminen and Kulmala, 2002) Eq. (8) is used in this context to check for the loss contribution and to check the sensitivity of individual hypothesis parameterisations.

\section{Results}

\subsection{Boundary layer transport dilution}

As noted earlier, the surface information on vegetation, its height and leaf area density was used to initialise the back trajectory boundary layer model. The outcome was treated as a function of wind direction and was subsequently scaled to the present wind speeds at $4 \mathrm{~m}$ above soil level. The resulting relative reduction for VOCs during the transport without any reactions is displayed in Fig. 5 for two different locations - i.e. the hill top, where formation rates and gases have been acquired as well as for the MoLa location, at which the entire particle size distribution has been measured. It is obvious that there were several periods of minor dilution (small transport times): at the start of measurements, at the day of the year (DOY) 233 and at the initial days of the second half (241-244). During these periods relative reduction was minor, while during the other times dilutions up to a tenth of the original values have occurred.

\subsection{VOCs and tropospheric basic trace gases}

This dilution certainly impacted on the VOC mixing ratios at the hill top. In Fig. 6 the volume mixing ratios of isoprene, mono- and sesquiterpenes are displayed at the forest edge close to the cuvette (top) and at the hill top in the centre of the clearing, where most of the measurements were performed and the formation of new particles was investigated. The cal-
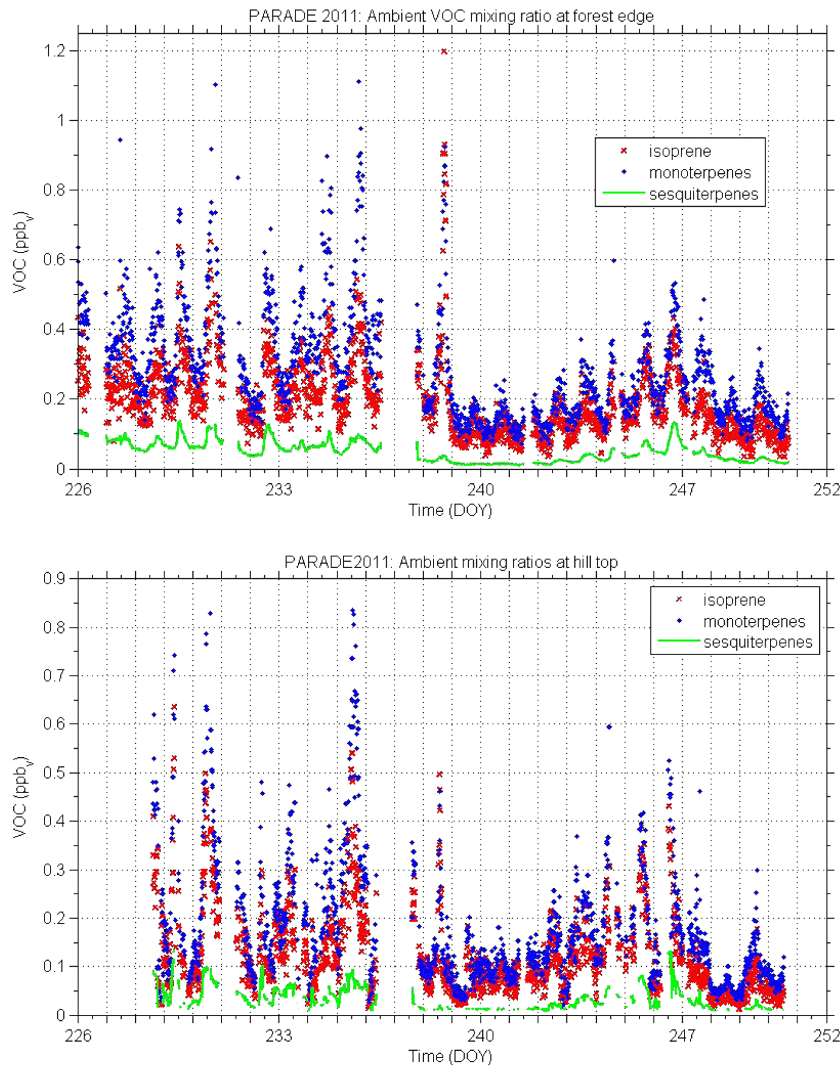

Figure 6. Measured volume mixing ratios at the forest edge (top) and calculated mixing ratios at the hill top (bottom) of isoprene, mono- and sesquiterpenes.

culated dilution matches the three different VOC measurements of Bourtsoukidis et al. (2014) and by the MPI Mainz (not shown) performed at the hill top reasonably. A clear decline is apparent for sesquiterpenes since these compounds are additionally reduced by the reaction with ambient ozone. Nevertheless, notable amounts were still present at the centre of the hill. The mean and extreme concentrations are listed in Table 3 .

\subsection{Ozone and NO}

Ozone values were measured at different places, i.e. at the hill top (reference), at the Hessian Agency for the Environment and Geology (Wiesbaden) container and at the forest edge (Fig. 7). In general a minor reduction from hill top to the trees $\left(-2.0 \pm 1.3 \mathrm{ppb}_{\mathrm{v}}\right)$ was detected, which was on average about $-3.7 \mathrm{ppb}_{\mathrm{v}}$ during daytime (higher at hill top) but changed to an increase of $+0.3 \mathrm{ppb}_{\mathrm{v}}$ during night-time (elevated at the forest). The difference is slightly smaller for the hill top and the HLUG measurements $\left(-1.9 \pm 4 \mathrm{ppb}_{\mathrm{v}}\right)$. Mean ozone mixing ratios at the hill top were $(44 \pm 15) \mathrm{ppb}_{\mathrm{v}}$. With respect to NO, the site is notably affected by the transport from Frankfurt and its surrounding traffic routes including motorways, train tracks and the airport. Mean daytime NO 
Table 3. Measured mean, minimum and maximum isoprene, mono- and sesquiterpene concentrations at the forest edge and at the 2011.

\begin{tabular}{|c|c|c|c|}
\hline $\begin{array}{l}\text { VOC, } \\
\text { forest edge }\end{array}$ & $\begin{array}{l}\text { Mean conc. } \\
{\left[\text { molec. } \mathrm{cm}^{-3}\right]}\end{array}$ & $\begin{array}{l}\text { Min. conc. } \\
{\left[\text { molec. } \mathrm{cm}^{-3}\right]}\end{array}$ & $\begin{array}{l}\text { Max. conc. } \\
{\left[\text { molec. } \mathrm{cm}^{-3}\right]}\end{array}$ \\
\hline Isoprene & $(4.5 \pm 2.5) \times 10^{9}$ & $0.8 \times 10^{9}$ & $2.8 \times 10^{10}$ \\
\hline Monoterpenes & $(6.5 \pm 3.6) \times 10^{9}$ & $1.7 \times 10^{9}$ & $2.6 \times 10^{10}$ \\
\hline Sesquiterpenes & $(1.1 \pm 0.6) \times 10^{9}$ & $2.3 \times 10^{8}$ & $3.1 \times 10^{9}$ \\
\hline $\begin{array}{l}\text { VOC, } \\
\text { hill top }\end{array}$ & $\begin{array}{l}\text { Mean conc. } \\
{\left[\text { molec. } \mathrm{cm}^{-3}\right]}\end{array}$ & $\begin{array}{l}\text { Min. conc. } \\
{\left[\text { molec. } \mathrm{cm}^{-3}\right]}\end{array}$ & $\begin{array}{l}\text { Max. conc. } \\
{\left[\text { molec. } \mathrm{cm}^{-3}\right]}\end{array}$ \\
\hline Isoprene & $(2.8 \pm 2.1) \times 10^{9}$ & $0.3 \times 10^{9}$ & $1.4 \times 10^{10}$ \\
\hline Monoterpenes & $(3.6 \pm 3.1) \times 10^{9}$ & $0.7 \times 10^{9}$ & $1.9 \times 10^{10}$ \\
\hline Sesquiterpenes & $(0.6 \pm 0.5) \times 10^{9}$ & $0.1 \times 10^{8}$ & $3.0 \times 10^{9}$ \\
\hline
\end{tabular}

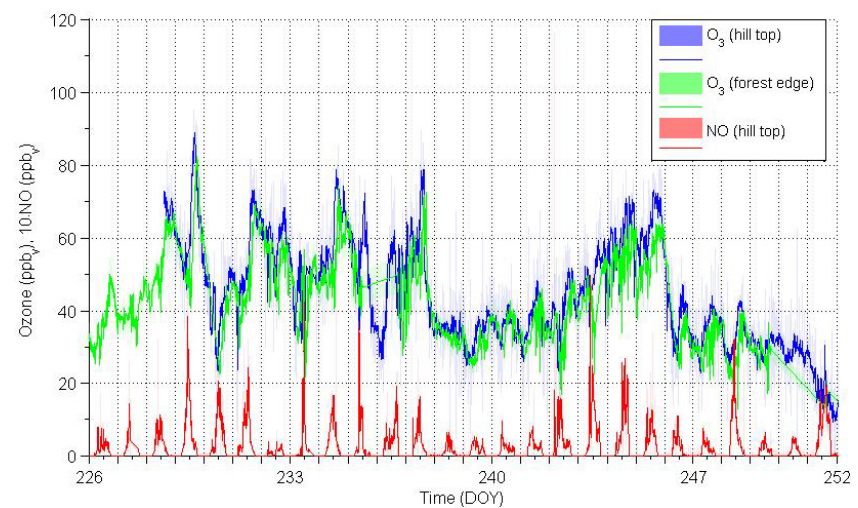

Figure 7. Detailed behaviour of detected ambient ozone and 10-fold increased NO mixing ratios. The detection limit of NO was $21 \mathrm{ppt}_{\mathrm{v}}$.

mixing ratios were $460 \mathrm{ppt}_{\mathrm{v}}$ and night-time ones in the order of $20 \mathrm{ppt}_{\mathrm{v}}$. Note that the detection limit for NO was $21 \mathrm{ppt}_{\mathrm{v}}$. The detailed pattern of ozone and NO measurements is provided in Fig. 7.

\section{4 $\mathrm{OH}$ and $\mathrm{NO}_{3}$}

For $\mathrm{OH}$ approximation individual values of different trace gas measurements and diluted VOCs were selected at the hill top. The results are displayed in Fig. 8 (upper graph) for both methods (see Sect. 3.4), with the black line representing approach (1) and with the red line for the $\mathrm{OH}$ reactivity approach on the right-hand $y$-axis. The expected daily pattern was found, i.e. showing a clear maximum at highest solar radiation intensity and minima during the nights. The maxima of individual days varied as a function of radiation intensity, cloudiness and air pollution between maximum values of several $10^{5}$ and nearly $10^{7} \mathrm{~cm}^{-3}$ at noon and values between 100 and $1000 \mathrm{~cm}^{-3}$ during night-time.

There are two periods with notable deviation between the $J\left(\mathrm{O}^{1} \mathrm{D}\right)$-related and the budgets approaches: the first one is the very first day of the measurements (DOY 226) and the second one is day 238. Both days were days of
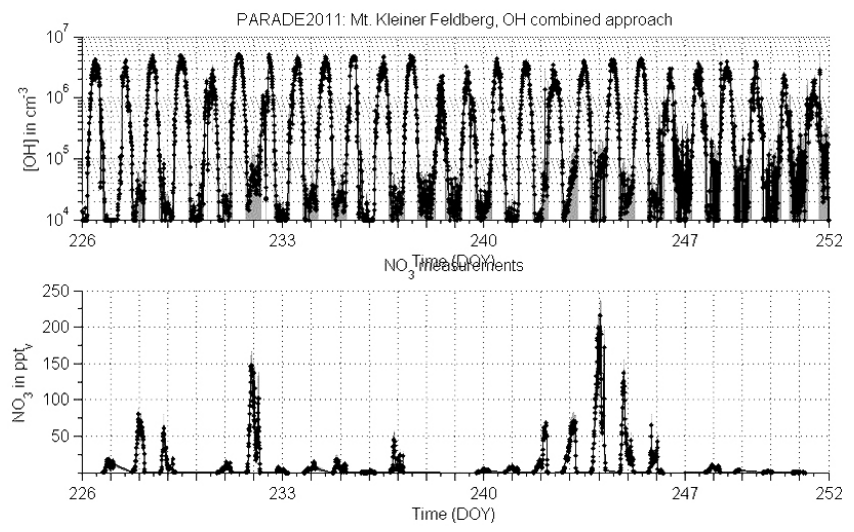

Figure 8. Top: calculated OH concentrations at the hill top. Bottom: detected $\mathrm{NO}_{3}$ radical mixing ratios at the same location.

high relative humidity values close to $100 \%$ for the entire day. Potentially this mismatch is caused by a water film on the plant cuvette surface, which might have affected the VOC measurement results and thus the sink terms that depend on the water uptake of soluble VOCs and the hydronium ion $\left(\mathrm{H}_{3} \mathrm{O}^{+}\right)$concentration, used for subsequent calculations. Those days were the most humid days during the entire seasonal measurements in 2011 and those exceptional periods occurred during these particular days only. The nitrate radicals $\left(\mathrm{NO}_{3}\right)$ were measured using Cavity RingDown spectroscopy (Crowley et al., 2010, 2011), and the data are displayed in the lower graph of Fig. 8. These exhibit the opposite behaviour with maximum concentrations during the night. Mean night-time $\mathrm{NO}_{3}$ mixing ratios were $(21 \pm 16)$ ppt $_{\mathrm{v}}$ with maximum values during the night between DOY 227 and 228, 231 and 232 as well as between 243 and 244 . The total maximum of $215 \mathrm{ppt}_{\mathrm{v}}$ was measured at DOY 244.1. 

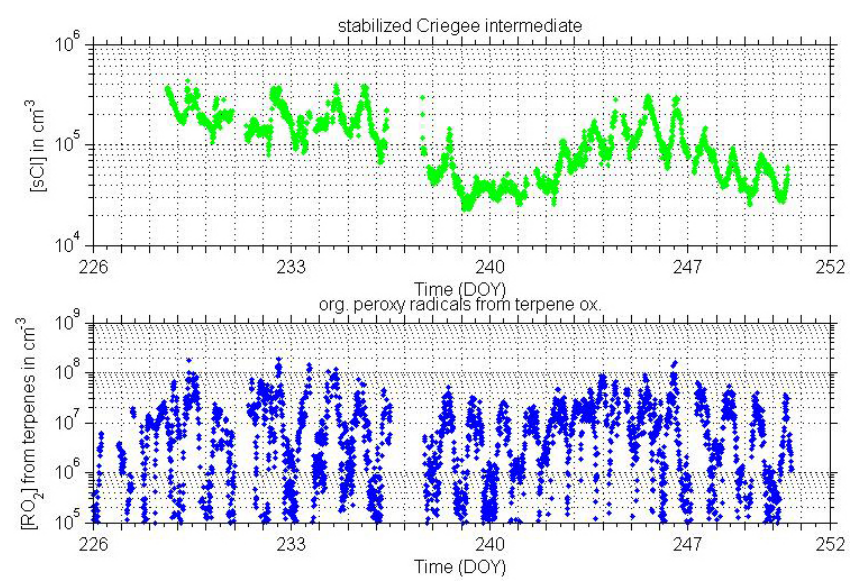

Figure 9. Top: estimated ambient stabilised Criegee Intermediates (sCI). Bottom: $\mathrm{RO}_{2}$ (terp.) radicals.

\subsection{VOC-based radicals}

Ten-minute-averaged concentrations of sesquiterpenes, ozone and water vapour have been used to approximate sCI concentrations and large $\mathrm{RO}_{2}$ concentrations based on the mass balance between sources and sinks (bottom graph in Fig. 9) according to

$$
\begin{aligned}
& {[\mathrm{sCl}] \approx \frac{k_{\mathrm{MT}}^{\mathrm{O}_{3}} \cdot[\mathrm{MT}]\left[\mathrm{O}_{3}\right] \cdot Y_{\mathrm{stab}, \mathrm{MT}}+k_{\mathrm{LI}}^{\mathrm{O}_{3}} \cdot[\text { Linalool }]\left[\mathrm{O}_{3}\right] \cdot Y_{\text {stab,LI }}}{k_{\mathrm{SCI}}^{\mathrm{H}_{2} \mathrm{O}} \cdot\left[\mathrm{H}_{2} \mathrm{O}\right]}} \\
& +\frac{k_{\mathrm{SQT}}^{\mathrm{O}_{3}} \cdot[\mathrm{SQT}]\left[\mathrm{O}_{3}\right] \cdot Y_{\mathrm{stab}, \mathrm{SQT}}}{80 \mathrm{~s}^{-1}} \\
& {\left[\mathrm{RO}_{2}(\text { terp, day) }]=\frac{\left(k_{\mathrm{MT}}^{\mathrm{OH}} \cdot[\mathrm{MT}]+k_{\mathrm{SQT}^{\mathrm{OH}}}^{\mathrm{OH}} \cdot[\mathrm{SQTT}]+\sum[\mathrm{TOX}, \mathrm{d}] \cdot k_{\mathrm{TOX}, \mathrm{d}}^{\mathrm{OH}}\right) \cdot[\mathrm{OH}]}{k_{\mathrm{RO}_{2}}^{\mathrm{HO}} \cdot\left[\mathrm{HO}_{2}\right]+k_{\mathrm{RO}_{2}}^{\mathrm{NO}} \cdot[\mathrm{NO}]+k_{\mathrm{RO}_{2}}^{\mathrm{RO}_{2}} \cdot\left[\mathrm{RO}_{2}\right]+k_{\mathrm{RO}_{2}}^{\mathrm{NO} O_{2}} \cdot\left[\mathrm{NO}_{3}\right]}\right.} \\
& \approx \frac{\left(k_{\mathrm{MT}}^{\mathrm{OH}} \cdot[\mathrm{MT}]+k_{\mathrm{SQT}}^{\mathrm{OH}} \cdot[\mathrm{SQT}]+\sum[\mathrm{TOX}, \mathrm{d}] \cdot k_{\mathrm{TOX}, \mathrm{d}}^{\mathrm{OH}}\right) \cdot[\mathrm{OH}]}{k_{\mathrm{RO}_{2}}^{\mathrm{HO}_{2}} \cdot\left[\mathrm{HO}_{2}\right]+k_{\mathrm{RO}_{2}}^{\mathrm{NO}} \cdot[\mathrm{NO}]} \\
& {\left[\mathrm{RO}_{2}(\text { terp, night }]=\frac{\left(k_{\mathrm{MT}}^{\mathrm{NO}} \cdot[\mathrm{MT}]+k_{\mathrm{SQT}}^{\mathrm{NO}_{3}} \cdot[\mathrm{SQTT}]+\sum[\mathrm{TOX}, \mathrm{n}] \cdot k_{\mathrm{TOX}, \mathrm{n}}\right) \cdot\left[\mathrm{NO}_{3}\right]}{\mathrm{NO}_{\mathrm{RO}_{2}} \cdot\left[\mathrm{HO}_{2}\right]+k_{\mathrm{RO}} \cdot[\mathrm{NO}]+k_{\mathrm{RO}_{2}}^{\mathrm{NO}} \cdot\left[\mathrm{RO}_{2}\right]+k_{\mathrm{RO}} \mathrm{NO}_{3} \cdot\left[\mathrm{NO}_{3}\right]}\right.} \\
& \approx \frac{\left(k_{\mathrm{MT}}^{\mathrm{NO}_{3}} \cdot[\mathrm{MT}]+k_{\mathrm{SQT}}^{\mathrm{NO}_{3}} \cdot[\mathrm{SQT}]+\sum[\mathrm{TOX}, \mathrm{n}] \cdot k_{\mathrm{TOX}, \mathrm{n}}^{\mathrm{NO}_{3}}\right) \cdot\left[\mathrm{NO}_{3}\right]}{k_{\mathrm{RO}}^{\mathrm{HO}_{2}} \cdot\left[\mathrm{HO}_{2}\right]+k_{\mathrm{RO}_{2}}^{\mathrm{NO}} \cdot[\mathrm{NO}]+k_{\mathrm{RO}}^{\mathrm{NO}_{3}} \cdot\left[\mathrm{NO}_{3}\right]}
\end{aligned}
$$

For both radical groups, i.e. $\mathrm{sCI}$ and $\mathrm{RO}_{2}$ (terp.) monoterpenes were the most important source class. Equation (9) displays the steady-state approach based on the ozonolysis reactions of monoterpenes, linalool and sesquiterpenes source and the predominant sink reaction with ambient water vapour for monoterpene and linalool derived $\mathrm{SCI}$, while the intramolecular SOZ formation of sesquiterpene-derived $\mathrm{sCI}$ is the major sink of the latter. $k_{x}^{y}$ constants represent reaction rate constants as provided by Bourtsoukidis et al. (2012); Shu and Atkinson (1994) and Atkinson et al. (2006), and $Y_{\text {stab, } i}$ abbreviates the stabilisation ratios of linalool or the sum of individual mono- and sesquiterpenes weighted by their con- tributions to the corresponding terpene class. The following values have been used: $Y_{\text {stab, } \mathrm{MT}}=0.4, Y_{\text {stab }, \mathrm{LI}}=0.4$ and $Y_{\text {stab, SQT }}=0.8$.

The sum of individual terpene oxidation product concentrations is abbreviated by ([TOX, i]) with a "d" for daytime and an " $\mathrm{n}$ " for night-time conditions. This sum times the corresponding reaction rate constants with $\mathrm{OH}\left(k_{\mathrm{TOX}, i}^{\mathrm{OH}}\right)$ included the following measured VOCs: nopinone/sabinaketone (mass $138 \mathrm{~g} \mathrm{~mole}^{-1}$ ), methyl chavicol (mass $148 \mathrm{~g} \mathrm{~mole}^{-1}$ ) (Bouvier-Brown et al., 2009), linalool (mass $154 \mathrm{~g} \mathrm{~mole}^{-1}$ ) and pinonaldehyde/limonaldehyde (mass $168 \mathrm{~g} \mathrm{~mole}^{-1}$ ). Nopinone and sabinaketone were not considered at nighttime because of their insignificant reaction rate constant. Since the molar mass was detected only and no structural information was available, the reaction rate constants of nopinone/sabinaketone as well as of pinonaldehyde/limonaldehyde were taken as the sum of the individual reaction rate constants times the individual contribution of the parent monoterpene to emission (see the Supplement).

With respect to the organic peroxy radicals two aspects are worth mentioning:

1. Isoprene forms smaller peroxy radicals $\left(\mathrm{RO}_{2}(\mathrm{C} \leq 5)\right)$ reducing the lifetime and thus the concentration of (very) large $\mathrm{RO}_{2}$ and therefore counteracting the activation (Kiendler-Scharr et al., 2009). Thus, this $\mathrm{RO}_{2}$ was considered only for the total sum of $\mathrm{RO}_{2}$ but not for the $\mathrm{RO}_{2}$ (terp.) provided in Eqs. (10)-(12).

2. Investigating the individual contributions to $\left[\mathrm{RO}_{2}(\mathrm{C}>5)\right]$ the contributions of sesquiterpenes and primary oxidation products of monoterpenes (ketones at $138 \mathrm{~g} \mathrm{~mole}^{-1}$ and aldehydes at $168 \mathrm{~g} \mathrm{~mole}^{-1}$ ) are generally minor $(10 \%)$. Thus the production of $\left[\mathrm{RO}_{2}(\mathrm{C}>5)\right]$ is found to be primarily controlled by the monoterpene oxidation.

The calculated $[\mathrm{sCI}]$ and $\left[\mathrm{RO}_{2}(\mathrm{C}>5)\right]$ can be seen in Fig. 9.

\subsection{Particle formation rate at $3 \mathrm{~nm}$}

Next, Eqs. (1)-(6) were used to calculate the formation rate at $3 \mathrm{~nm}$ based on the theories (A), (B) and (C). The apparent $J_{3}$ was calculated as the change in interval number concentration between 3 and $5 \mathrm{~nm}$ and divided by $600 \mathrm{~s}$ due to the time resolution of $10 \mathrm{~min}$ of all measurements. Negative values as well as values below $10^{-3} \mathrm{~cm}^{-3} \mathrm{~s}^{-1}$ were excluded because of the focus on formation and because of the high uncertainty below the smallest value (count rate smaller than 1). A similar approach was done for obtaining $J_{5}$ that was derived from WCPC measurements (Table 1).

All derived values are displayed in Fig. 10 (top) and zoomed in the bottom plot for the third week with best quantitative measurements available. It is obvious that the total formation rate of particles is rather similar in structure for most of the days with about $0.1 \mathrm{~cm}^{-3} \mathrm{~s}^{-1}$ during midnight 

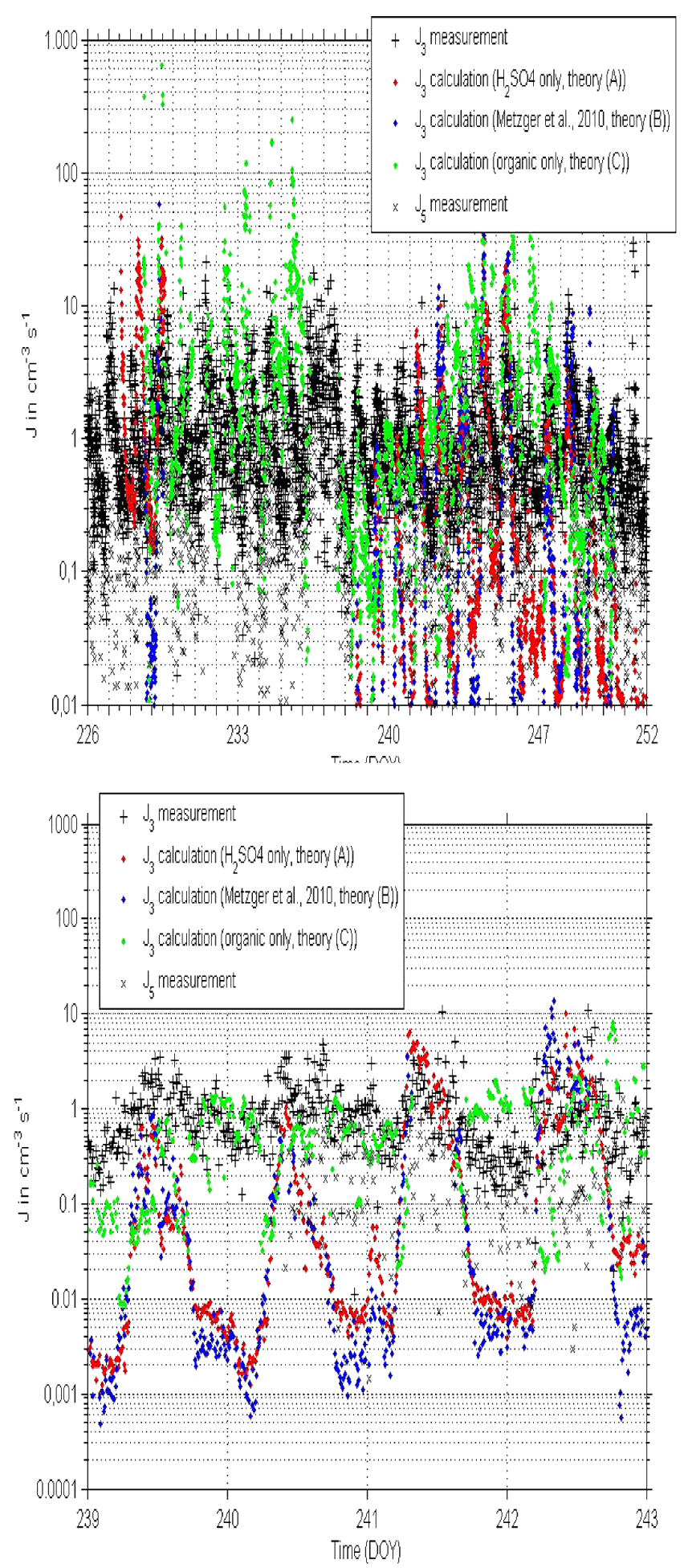

Figure 10. Top: measured and derived particle formation rates at $3 \mathrm{~nm}$ in particle diameter; bottom: at $5 \mathrm{~nm}$. The focus on five days only is in order to show the behaviour at different times of the day.

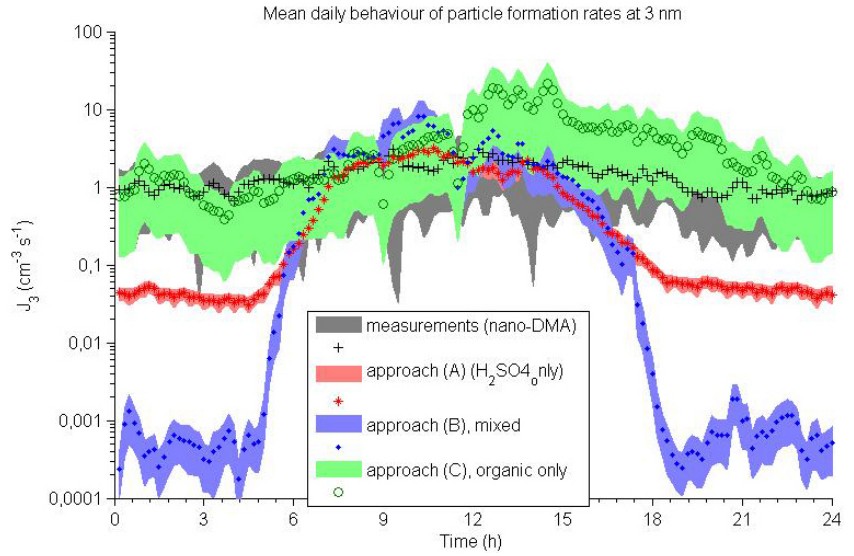

Figure 11. Mean daily pattern of measured and calculated particle formation rates at $3 \mathrm{~nm}$ diameter.

and a maximum of about $100 \mathrm{~cm}^{-3} \mathrm{~s}^{-1}$ during daytime. During the four weeks of campaign the first ten days were found to have the greatest $J_{3}$ with smaller values between DOY 238 and 240 followed by a subsequent rise towards the end of the measurement period. None of the three different theories could be compared to the full data set, since data gaps occurred particularly for sulfuric acid and VOCs. Therefore we concentrate on the periods of data availability for nearly all of the compounds, i.e. the start and the second half of the campaign. The peaks in $J_{3}$ at daily noon-time were calculated by all of the theories, since the entire process seems to be controlled by $\mathrm{OH}$ and the condensation sink. However, individual theories indicate a different daily variation. While the organic-only hypothesis $(\mathrm{C})$ displays a moderate daily variability due to the permanent presence of VOCs, the availability of ozone and the rather cloudy or rainy conditions, the hypotheses (B) and (A) show substantially greater variability between night- and day-time. The more the hypothesis is bound to sulfuric acid only the stronger the difference between night and day. This is shown in the bottom graph in Fig. 10. In matching the diurnal cycle, theory (C) performs best. In order to check whether the exact corresponding size of the particle formation rate matters for the intercomparison, results of particle formation rates at 3 and $5 \mathrm{~nm}$ are both shown.

This different behaviour is obvious in the mean daily pattern by the measured and the calculated formation rates in Fig. 11. Both approaches (A) and (B) display a strong daily variation, while the organic-based approach (C) does not. The reason for this difference is actually the different origins of large organic peroxy radicals at day- $(\mathrm{OH})$ and night-time $\left(\mathrm{NO}_{3}\right)$ and the different limitations in the minimum term (Sect. E in the Supplement). This minimum function in Eq. (5) results in a sCI limitation at night-time with notable amounts of large $\mathrm{RO}_{2}$ due to high levels of $\mathrm{NO}_{3}$, while at daytime the approach (C) is limited by the large monoterpene-derived $\mathrm{RO}_{2}$. 
A rather important aspect is the inhomogeneity of the surface resulting in a notable change in local concentrations and sinks, which are measurement point dependent. As different gases and the aerosol size distribution have been measured at different places (Fig. 2) because of logistical issues including availability of instrumentation and tubing losses in case of longer sampling lines, the exact merging of the entire data set is affected by meteorological transport within the boundary layer. The approach of calculating the transport dilution of terpenes and in this case especially the highly reactive sesquiterpenes is a reasonable approach but is limited by notable uncertainties in their loss intensity during the transport. We propose that it may serve as an order of magnitude estimate for cases of larger dilution as a function of the wind distribution and of longer transport times. Most of the deviations of the organic-only hypothesis (C) actually occur exactly in situations of remarkable dilution and notable changes across the hill top. Therefore a spatially resolved 3-D simulation might be useful in future work. Other compounds such as sulfuric acid should be less dependent on local dilution, because of the production of sulfuric acid by sulfur dioxide that has been advected.

\subsection{Loss between 3 and $5 \mathrm{~nm}$}

The next section will be used to investigate the size sensitivity of the formation rates that have been measured and calculated. As stated in Eq. (8), the loss between two sizes depends on $\mathrm{CS}^{\prime}$ and GR. Both describe all sink and growth terms of distinct particles i.e. the loss onto present aerosol surface area (CS) and the uptake of gas molecules that is the acquisition of mass (GR).

$\mathrm{CS}^{\prime}$ in the unit s${ }^{-1}$ (CS) is shown in Fig. 14 (top) as well as GR in the bottom graph. A nearly uniform structure of CS between $10^{-2}$ and $10^{-3} \mathrm{~s}^{-1}$ is visible for Taunus Observatory. Note that the coagulation sink (CoagS) term for $3 \mathrm{~nm}$ particles is shown too. It is slightly smaller due to the reduced diffusivity of smallest particles compared to gas molecules. GR is more difficult to obtain as the growth rate at smallest sizes is hard to achieve. Here we use a novel approach and crosscorrelate the $\mathrm{OH}$-concentration that is related to the initial formation process and the formation rate at a certain size. For completeness the correlation with $\mathrm{RO}_{2}$ and $\mathrm{H}_{2} \mathrm{SO}_{4}$ is shown as well (Fig. 12, top). The maximum correlation within four hours is assumed as the time taken to grow from nucleation size (ca. $1.2 \mathrm{~nm}$ ) to the formation rate size, e.g. $3 \mathrm{~nm}$, thus a minimum GR $(1.2-3 \mathrm{~nm})$ of $0.5 \mathrm{~nm} \mathrm{~h}^{-1}$ needs to be present for resolving it.

The cross-correlation analysis works as follows: two parameters are checked for similarity in structures i.e. pattern, maxima and minima locations. A perfect fit would result in a value of unity, and a perfect anticyclic behaviour in -1 . Next, the correlation of parameters is calculated by shifting one parameter data set in time (time shift displayed), while the second parameter data set is kept constant. In this context
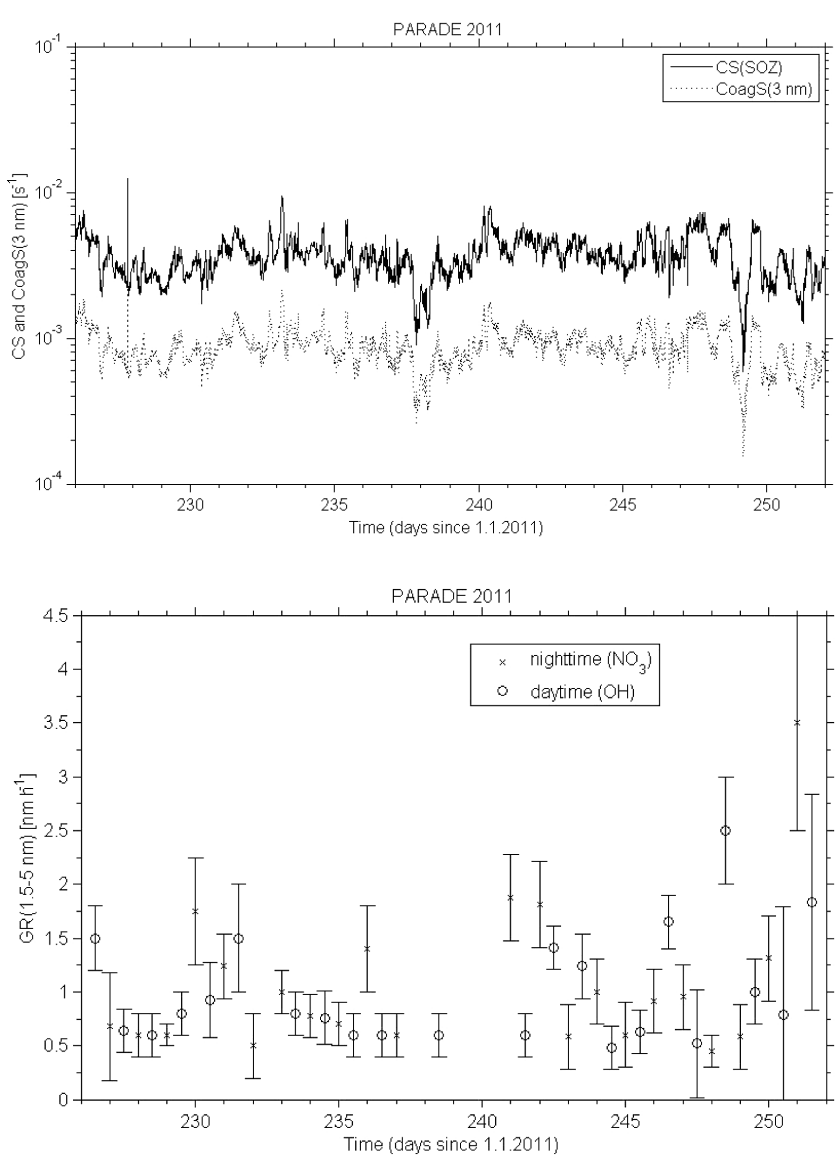

Figure 12. Top: calculated condensation (CS) and coagulation sinks $(\mathrm{CoagS}(3 \mathrm{~nm}))$ Bottom: mean growth rates $(\mathrm{GR})$ of clusters or particles between 1.5 and $5 \mathrm{~nm}$ in diameter.

the second parameter is the formation rate $J_{3}$ while the gases data sets are shifted in time. The larger the difference the earlier the same pattern must have appeared at the corresponding trace gas, thus the earlier the gas must have participated in the nucleation and formation process. Apparently the time shift is largest for $\mathrm{OH}$. Thus, it is the most likely relevant species for the first step of formation. The shift is gently smaller for monoterpene-derived $\mathrm{RO}_{2}$ and nearly no time shift is visible for $\mathrm{H}_{2} \mathrm{SO}_{4}$. This might suggest that sulfuric acid participates in the formation process at the latest stage. However since the process is non-linear and small amounts of sulfuric acid may be sufficient, this is not a disproof for hypothesis (A), only an indication. In order to check how the $\mathrm{OH}$ estimation impacts on the results, the bottom graph in Fig. 13 is added in order to display both structures, i.e. of $\mathrm{OH}$ calculation by using $\mathrm{OH}$ reactivity for all sink terms and by using the detailed chemistry calculations of all compounds considered. Only a minor change is obvious.

The derived GRs are shown in Fig. 12 (bottom). Applying those values in Eq. (6) the loss between 3 and $5 \mathrm{~nm}$ was calculated (Fig. 14). A loss between 1 and $16 \%$ was found. The 

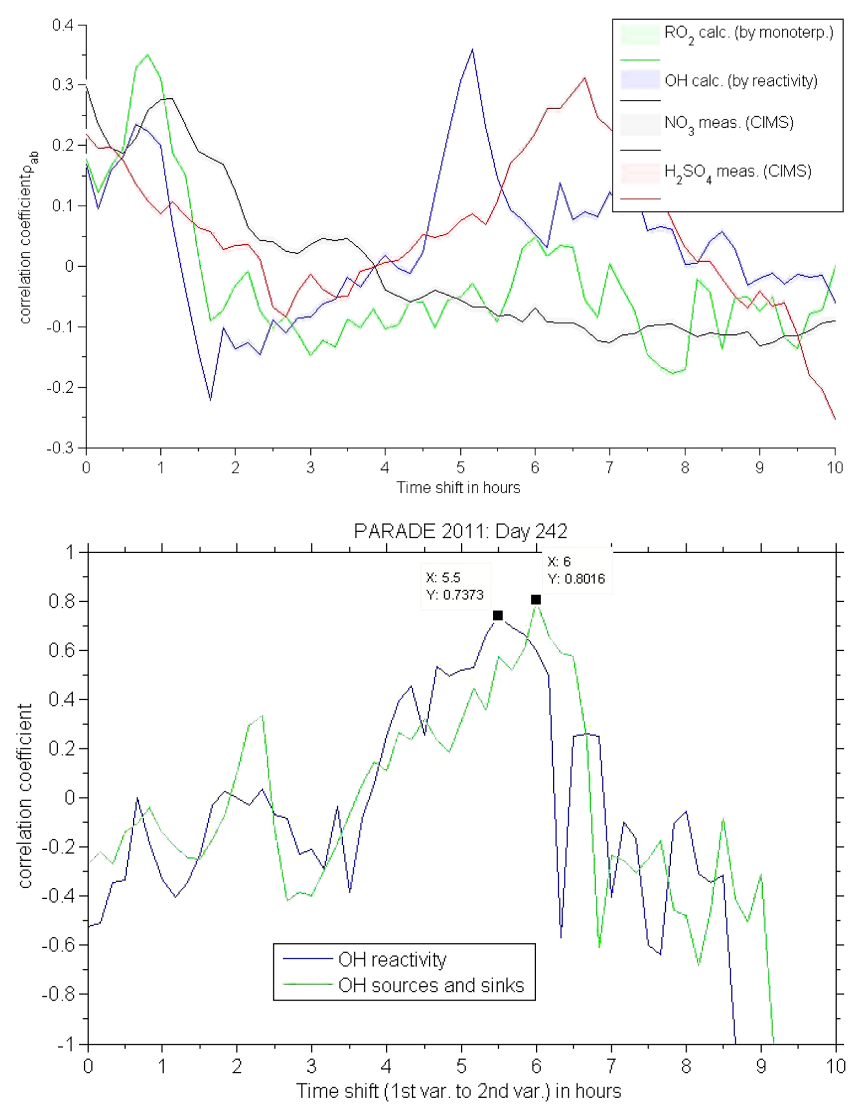

Figure 13. Top: cross-correlation of particle formation at $5 \mathrm{~nm}$ with $\mathrm{RO}_{2}$ (terp.), $\mathrm{OH}, \mathrm{NO}_{3}$ and $\mathrm{H}_{2} \mathrm{SO}_{4}$. Bottom: cross-correlation between the particle formation rate at $5 \mathrm{~nm}$ and the estimated $\mathrm{OH}$ concentration using two different approaches. The maximum is found at $\tau$ of $5.5 \mathrm{~h}$ ( $6 \mathrm{~h}$ for the budget approach), resulting in a GR of $3.5 \mathrm{~nm} / 5.5 \mathrm{~h}=0.6 \mathrm{~nm} \mathrm{~h}^{-1}$.

measurement time is evidently split into two periods, the first part with a negligible loss and notable growth rates and the second part after DOY 240 with relative losses above $10 \%$.

$J_{5}$ is shown as well. It can be seen that sometimes the organic-only hypothesis formation rate slows down to the $J_{5}$ value. That might be caused by the notable variety of input parameters for calculation, i.e. the exact dilution especially at elevated wind speeds and the corresponding variability of the terpenes and thus the $\mathrm{RO}_{2}$ (terp) as mentioned above. However, at the mean daily behaviour, i.e. averaging all values at identical times throughout the campaign days, the organic hypothesis $(\mathrm{C})$ matches best with a notable uncertainty range because of the multitude of parameters used for the calculations. Both other hypotheses (A) and (B) fit well at noon but display an increasing deviation towards the night-time (Fig. S9 in the Supplement).

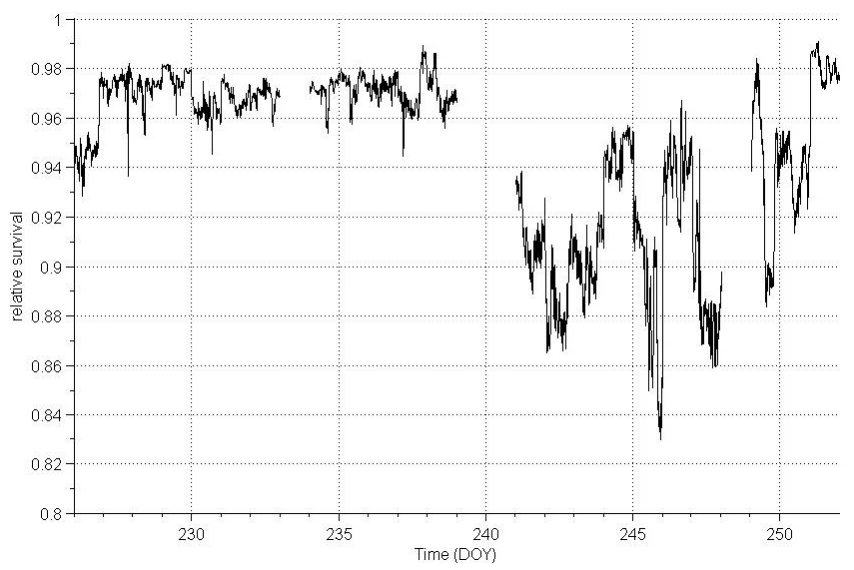

Figure 14. Calculated relative survival of particles during growth from 3 to $5 \mathrm{~nm}$.

\subsection{The link of particle formation rates to radicals}

We have discussed the initial step(s) of new cluster formation and the loss intensity during the first growth from cluster to particle sizes in the previous sections. In any of the three nucleation mechanisms the activation and growth are controlled by different processes: (i) next to forming the nucleation nuclei the nuclei are activated (grown) by reactions forming products of substantial mass gain. As condensation is hard to realise because of the high Kelvin effect at the size of $1-1.5 \mathrm{~nm}$ in diameter and substantial partitioning is impossible due to a lack of organic and water mass, the reaction of reactive species e.g. radicals remains the only way available. These radicals will form adducts that fix the reactants to the nuclei if they are sufficiently large $(\mathrm{C}$ number $>5$, Wolf et al., 2009). According to Bonn et al. (2008) and Wolf et al. (2009) any isoprene-related organic radical is too small, while mono- and sesquiterpene related radicals are of acceptable size. Therefore, isoprene is supposed to suppress the formation of totally new particles and only produce particulate mass via partitioning or acid-catalysed reactions (Surratt et al., 2010; Lin et al., 2012; Nguyen et al., 2013) while monoand sesquiterpene oxidation products contribute to both, i.e. number and mass production. It is important to note too that certainly all radicals such as $\mathrm{HO}_{2}$ and any $\mathrm{RO}_{2}$ may react with the intermediate products. Some are supposed to lead to at least temporarily stable products. But only the reactions with $\mathrm{RO}_{2}(\mathrm{C}>5)$ and with sCI cause a substantial mass increase before the cluster or small particle is been lost on preexisting larger particle surfaces. In both reactions, i.e. with $\mathrm{HO}_{2}$ and with $\mathrm{RO}_{2}(\mathrm{C}>5)$, the products are of similar type including an $\mathrm{O}-\mathrm{O}$ bond that differs in mass. The detailed individual role of $\mathrm{HO}_{2}$ and $\mathrm{RO}_{2}(\mathrm{C}>5)$ reactions remains an issue for further study.

The second stage of size increase is the further growth including condensation and partitioning as size increases. This is supposed to dominate above a diameter of $5-10 \mathrm{~nm}$ 

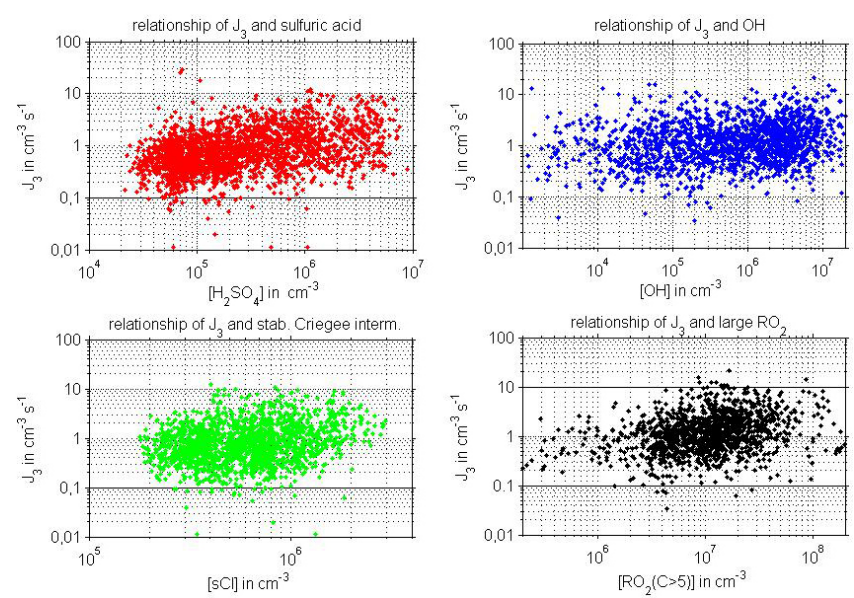

Figure 15. Scatter plots of sulfuric acid, $\mathrm{OH}$, stabilised Criegee intermediates and large organic peroxy radicals by monoterpene oxidation $\left(\mathrm{RO}_{2}\right.$ (terp)) with the particle formation rate at $3 \mathrm{~nm}$.

and thus dominate the growth rates usually gained from measurements. This second step has been investigated in a multitude of studies and ascribed to mainly low- and semivolatile organics. What remains to be analysed in this study is the contribution of radicals such as the $\mathrm{sCI}$ and the large $\mathrm{RO}_{2}(\mathrm{C}>5)$ to the first step of nucleation following the nuclei or cluster formation. These radicals assume an important role in the third (organic only) and probably in the second (organic-sulfuric acid) based nucleation mechanisms. This link between formation $\left(J_{3}\right)$ and growth rates at smallest sizes GR $(3-5 \mathrm{~nm})$ and different radicals will be addressed in what follows. As sulfuric acid is the major agent of mechanism 1 (sulfuric acid only) and probably of mechanism 2 as well, $\mathrm{H}_{2} \mathrm{SO}_{4}$ is included in these considerations as well. An overview is presented in Fig. 15. It is apparent that all radicals and sulfuric acid display a linear relationship. The upper graphs of sulfuric acid and $\mathrm{OH}$ show a similar structure as the presence of sulfuric acid is highly connected with the presence of $\mathrm{OH}$. The behaviour is seen for the stabilised Criegee intermediates primarily formed by monoterpenes and ozone and the large organic peroxy radicals primarily produced from monoterpene reactions with $\mathrm{OH}$. It is apparent that there is more scatter in the lower graphs $\left(\mathrm{sCI}\right.$ and $\mathrm{RO}_{2}(\mathrm{C}>5)$ ) compared to the upper graphs of sulfuric acid and $\mathrm{OH}$. This is caused by two aspects: (i) measurements of sulfuric acid and $\mathrm{OH}$ were available only for the last ten days of the campaign with improved meteorological conditions and (ii) $\mathrm{sCI}$ and $\mathrm{RO}_{2}(\mathrm{C}>5)$ depend on a significant number of measurements and parameters such as VOC, dilution and oxidation speed of the potentially varying mixture in time. However, $\mathrm{H}_{2} \mathrm{SO}_{4}, \mathrm{OH}$ and $\mathrm{RO}_{2}(\mathrm{C}>5$ ) display a clear relationship (see Supplement Table S1). Correlations are also apparent for stabilised CI but the uncertainty of the derived relationship is significant. The general link to the particle formation rate at $3 \mathrm{~nm}$ is obvious as, except for sCI intermediates, all depend

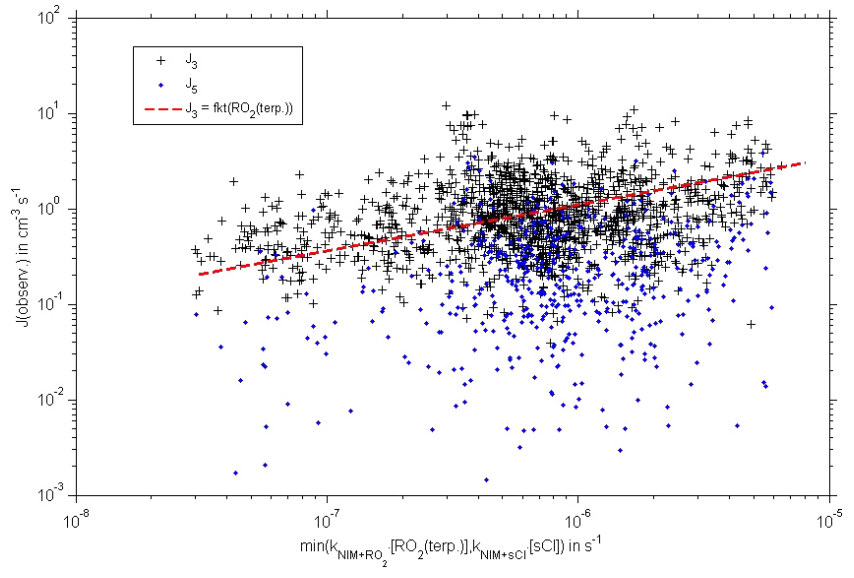

Figure 16. Scatter plot of the activation term in Eq. (5) vs. the formation rates at 3 and $5 \mathrm{~nm}$.

on $\mathrm{OH}$ and thus provide a similar slope structure. The relationship of the reaction-controlled activation term of Eq. (3) and the particle formation rates at 3 and $5 \mathrm{~nm}$ is displayed in Fig. 16. A link is visible.

\section{Conclusions}

In this study the potential link between ambient organic radical species and new particle formation rates has been investigated. Observations of gas-phase and aerosol species were made during a 4 week intensive field campaign at the Taunus Observatory in Central Germany. Different particle formation hypotheses have been intercompared with observed particle formation rates at $3 \mathrm{~nm}$ particle size. While the simplified theories based only on concentrations of gas phase sulfuric acid were able to reproduce the maximum formation rates observed around local noon they were unable to reproduce the observed daily variability. Nucleation theories that involved the concentrations of organic radical species better matched the observed daily cycle in particle formation rate. Based on previous laboratory findings, the observations have been interpreted by the interaction of biogenic sesqui- and monoterpenes with ozone, $\mathrm{OH}$ and $\mathrm{NO}_{3}$. It is the first time that the particle formation rate at or above a forest has been explained by a detailed nucleation scheme that is based on laboratory data and with a predominant role of ambient organic radicals. We have suggested that different biogenic alkenes may take different roles in the formation process: sesquiterpenes may form nucleation cores by reacting with ambient ozone, while monoterpenes may form activating radicals by reaction with $\mathrm{OH}$ and $\mathrm{NO}_{3}$. This link between ambient radicals and new particle formation has not been reported so far and may explain the diversity of formation and growth rates observed at different locations and chemical conditions $\left(\mathrm{NO}_{\mathrm{x}}, \mathrm{HO}_{\mathrm{x}}\right.$ and $\left.\mathrm{RO}_{2}\right)$. Our proposed nucleation scheme is also capable of explaining the isoprene 
suppression effect on particle formation (Kiendler-Scharr et al., 2009), since isoprene reacts with $\mathrm{OH}$ and $\mathrm{NO}_{3}$ producing smaller organic peroxy radicals that do not activate but affect the larger radicals' lifetime. If so, this behaviour would have consequences for the climate change feedback cycles of different ecosystems (Spracklen et al., 2008) and would provide an important key to understanding the atmospheric impacts of biome change under changing climatic conditions.

\section{The Supplement related to this article is available online at doi:10.5194/acp-14-10823-2014-supplement.}

Acknowledgements. We would like to thank all participants and supporters of the PARADE field campaign 2011 at Taunus Observatory not included in the list of authors (B. Bohn, B. Bühner, J. Crowley, W. Haunold, A. Kürten, J. Curtius, K. Hens, H. Harder, A. Novelli, J. Fachinger, F. Drewnick, H. Fischer, G. Phillips, J. Thieser, A. Reiffs, A. Nölscher, J. Williams and R. Sitals) for sharing their data and comments and a wet but nice field campaign. In particular, Birger Bohn, Hartwig Harder and Korbinian Hens are acknowledged for the intensive discussion about the $\mathrm{OH}$ derivation and reliability.

Edited by: F. Keutsch

\section{References}

Atkinson, R., Baulch, D. L., Cox, R. A., Crowley, J. N., Hampson, R. F., Hynes, R. G., Jenkin, M. E., Rossi, M. J., Troe, J., and IUPAC Subcommittee: Evaluated kinetic and photochemical data for atmospheric chemistry: Volume II - gas phase reactions of organic species, Atmos. Chem. Phys., 6, 3625-4055, doi:10.5194/acp-6-3625-2006, 2006.

Barsanti, K. C. and Pankow, J. F.: Thermodynamics of the formation of atmospheric organic particulate matter by accretion reactions - part 1: Aldehydes and ketones, Atmos. Environ., 38, 43714382, 2004.

Barsanti, K. C. and Pankow, J. F.: Thermodynamics of the formation of atmospheric organic particulate matter by accretion reactions -2. dialdehydes, methylglyoxal, and diketones, Atmos. Environ., 39, 6597-6607, 2005.

Barsanti, K. C. and Pankow, J. F.: Thermodynamics of the formation of atmospheric organic particulate matter by accretion reactions - part 3: Carboxylic and dicarboxylic acids, Atmos. Environ., 40, 6676-6686, 2006.

Beck, M., Winterhalter, R., Hermann, F., and Moortgat, G. K.: The gas-phase ozonolysis of $\alpha$-humulene, Phys. Chem. Chem. Phys., 13, 10970-11001, 2011.

Bohn, B., Corlett, G. K., Gillmann, M., Sanghavi, S., Stange, G., Tensing, E., Vrekoussis, M., Bloss, W. J., Clapp, L. J., Kortner, M., Dorn, H.-P., Monks, P. S., Platt, U., PlassDülmer, C., Mihalopoulos, N., Heard, D. E., Clemitshaw, K. C., Meixner, F. X., Prevot, A. S. H., and Schmitt, R.: Photolysis frequency measurement techniques: results of a comparison within the ACCENT project, Atmos. Chem. Phys., 8, 53735391, doi:10.5194/acp-8-5373-2008, 2008.

Bonn, B. and Moortgat, G. K.: Sesquiterpene ozonolysis: Origin of atmospheric new particle formation from biogenic hydrocarbons, Geopys. Res. Lett., 30, 1585, doi:10.1029/2003GL017000, 2003.

Bonn, B., Schuster, G., and Moortgat, G. K.: Influence of water vapor on the process of new particle formation during monoterpene ozonolysis, J. Phys. Chem. A, 106, 2869-2881, 2002.

Bonn, B., Korhonen, H., Petäjä, T., Boy, M., and Kulmala, M.: Understanding the formation of biogenic secondary organic aerosol from $\alpha$-pinene in smog chamber studies: role of organic peroxy radicals, Atmos. Chem. Phys. Discuss., 7, 3901-3939, doi:10.5194/acpd-7-3901-2007, 2007.

Bonn, B., Kulmala, M., Riipinen, I., Sihto, S.-L., and Ruuskanen, T. M.: How biogenic terpenes govern the correlation between sulfuric acid concentrations and new particle formation, J. Geophys. Res., 113, D12209, doi:10.1029/2007JD009327, 2008.

Bonn, B., Boy, M., Kulmala, M., Groth, A., Trawny, K., Borchert, S., and Jacobi, S.: A new parametrization for ambient particle formation over coniferous forests and its potential implications for the future, Atmos. Chem. Phys., 9, 8079-8090, doi:10.5194/acp-9-8079-2009, 2009.

Bourtsoukidis, E., Bonn, B., Dittmann, A., Hakola, H., Hellén, H., and Jacobi, S.: Ozone stress as a driving force of sesquiterpene emissions: a suggested parameterisation, Biogeosciences, 9, 4337-4352, doi:10.5194/bg-9-4337-2012, 2012.

Bourtsoukidis, E., Williams, J., Kesselmeier, J., Jacobi, S., and Bonn, B.: From emissions to ambient mixing ratios: online seasonal field measurements of volatile organic compounds over a Norway spruce-dominated forest in central Germany, Atmos. Chem. Phys., 14, 6495-6510, doi:10.5194/acp-14-6495-2014, 2014.

Bouvier-Brown, N. C., Holzinger, R., Palitzsch, K., and Goldstein, A. H.: Large emissions of sesquiterpenes and methyl chavicol quantified from branch enclosure measurements, Atmos. Environ., 43, 389-401, 2009.

Burkholder, J. B., Curtius, J., Ravishankara, A. R., and Lovejoy, E. R.: Laboratory studies of the homogeneous nucleation of iodine oxides, Atmos. Chem. Phys., 4, 19-34, doi:10.5194/acp4-19-2004, 2004.

Carslaw, K. S., Boucher, O., Spracklen, D. V., Mann, G. W., Rae, J. G. L., Woodward, S., and Kulmala, M.: A review of natural aerosol interactions and feedbacks within the Earth system, Atmos. Chem. Phys., 10, 1701-1737, doi:10.5194/acp-10-17012010, 2010.

Criegee, R.: Mechanismus der Ozonolyse, Angew. Chem., 87, 765$771,1975$.

Crowley, J. N., Schuster, G., Pouvesle, N., Parchatka, U., Fischer, H., Bonn, B., Bingemer, H., and Lelieveld, J.: Nocturnal nitrogen oxides at a rural mountain-site in south-western Germany, Atmos. Chem. Phys., 10, 2795-2812, doi:10.5194/acp-10-27952010, 2010.

Crowley, J. N., Thieser, J., Tang, M. J., Schuster, G., Bozem, H., Beygi, Z. H., Fischer, H., Diesch, J.-M., Drewnick, F., Borrmann, S., Song, W., Yassaa, N., Williams, J., Pöhler, D., Platt, U., and Lelieveld, J.: Variable lifetimes and loss mechanisms for $\mathrm{NO}_{3}$ and $\mathrm{N}_{2} \mathrm{O}_{5}$ during the DOMINO campaign: contrasts between marine, urban and continental air, Atmos. 
Chem. Phys., 11, 10853-10870, doi:10.5194/acp-11-108532011, 2011.

Dal Maso, M., Kulmala, M., Riipinen, I., Wagner, R., Hussein, T., Aalto, P. P., and Lehtinen, K. E. J.: Formation and growth of fresh atmospheric aerosols: eight years of aerosol size distribution data from SMEAR II, Hyytiälä, Boreal Environ. Res., 5, 323-336, 2005.

Donahue, N. M., Robinson, A. L., Stanier, C. O., and Pandis, S. N.: Coupled partitioning, dilution, and chemical aging of semivolatile organics, Environ. Sci. Technol., 40, 2635-2643, 2006

Donahue, N. M., Trump, E. R., Pierce, J. R., and Riipinen, I.: Theoretical constraints on pure vapor pressure driven condensation of organics to ultrafine particles, Geophys. Res. Lett., 38, L16801, doi:10.1029/2011GL048115, 2011.

Drewnick, F., Böttger, T., von der Weiden-Reinmüller, S.-L., Zorn, S. R., Klimach, T., Schneider, J., and Borrmann, S.: Design of a mobile aerosol research laboratory and data processing tools for effective stationary and mobile field measurements, Atmos. Meas. Tech., 5, 1443-1457, doi:10.5194/amt-5-1443-2012, 2012.

Ebach, F.: Simulation der Grössenverteilung von organischen Aerosolen während der Alken-Ozon-Reaktion unter dem Einfluss von NO, Master's thesis, J. W. Goethe-University, Frankfurt (Main), 2010

Friedlander, S. K.: Smoke, Dust and Haze: Fundamentals of Aerosol Dynamics, Oxford Univ. Press, New York, 407 pp., 2000.

Großmann, D.: Die Gasphasenozonolyse von Alkenen in Gegenwart von Wasserdampf als Quelle für Wasserstoffperoxid und organische Peroxide in der Atmosphäre, $\mathrm{PhD}$ thesis, J. GutenbergUniversity, Mainz, 1999.

Guenther, A., Hewitt, C. N., Erickson, D., Fall, R., Geron, C., Graedel, T., Harley, P., Klinger, L., Lerdau, M., McKay, W. A., Pierce, T., Scholes, B., Steinbrecher, R., Tallamraju, R., Taylor, J., and Zimmerman, P.: A global model of natual volatile organic compound emissions, J. Geophys. Res., 100, 8873-8892, 1995.

Guenther, A., Karl, T., Harley, P., Wiedinmyer, C., Palmer, P. I., and Geron, C.: Estimates of global terrestrial isoprene emissions using MEGAN (Model of Emissions of Gases and Aerosols from Nature), Atmos. Chem. Phys., 6, 3181-3210, doi:10.5194/acp-63181-2006, 2006.

Hakola, H., Tarvainen, V., Bäck, J., Ranta, H., Bonn, B., Rinne, J., and Kulmala, M.: Seasonal variation of mono- and sesquiterpene emission rates of Scots pine, Biogeosciences, 6, 93-101, doi:10.5194/bg-6-93-2006, 2006.

Handisides, G. M., Plass-Dülmer, C., Gilge, S., Bingemer, H., and Berresheim, H.: Hohenpeissenberg Photochemical Experiment (HOPE 2000): Measurements and photostationary state calculations of $\mathrm{OH}$ and peroxy radicals, Atmos. Chem. Phys., 3, 15651588, doi:10.5194/acp-3-1565-2003, 2003.

Hirsikko, A., Nieminen, T., Gagné, S., Lehtipalo, S. K., Manninen, H. E., Ehn, M., Hõrrak, U., Kerminen, V.-M., Laakso, L., McMurry, P. H., Mirme, A., Mirme, S., Petäjä, T., Tammet, H., Vakkari, V., Vana, M., and Kulmala, M.: Atmospheric ions and nucleation: a review of observations, Atmos. Chem. Phys., 11, 767-798, doi:10.5194/acp-11-767-2011, 2011.
Hoffmann, T., Odum, J., Bowman, F., Collins, D., Klockow, D., Flagan, R. C., and Seinfeld, J. H.: Formation of organic aerosols from the oxidation of biogenic hydrocarbons, J. Atmos. Chem., 26, 189-222, 1997.

Hummel, M.: Laborstudie zum Beitrag organischer Peroxyradikale $\left(\mathrm{RO}_{2}\right)$ bei der Partikelneubildung während der Ethen-OzonReaktion, Master's thesis, J. W. Goethe-University, Frankfurt (Main), 2010.

Hyvönen, S., Junninen, H., Laakso, L., Dal Maso, M., Grönholm, T., Bonn, B., Keronen, P., Aalto, P., Hiltunen, V., Pohja, T., Launiainen, S., Hari, P., Mannila, H., and Kulmala, M.: A look at aerosol formation using data mining techniques, Atmos. Chem. Phys., 5, 3345-3356, doi:10.5194/acp-5-3345-2005, 2005.

Jacobson, M. Z.: Fundamentals of Atmospheric Modeling, 2nd edn., Cambridge Univ. Press, New York, 813 pp., 2005.

Jenkin, M. E., Saunders, S. M., and Pilling, M. J.: The tropospheric degradation of volatile organic compounds: a protocol for mechanism development, Atmos. Environ., 31, 81-104, 1997.

Jenkin, M. E., Saunders, S. M., Wagner, V., and Pilling, M. J.: Protocol for the development of the Master Chemical Mechanism, MCM v3 (Part B): tropospheric degradation of aromatic volatile organic compounds, Atmos. Chem. Phys., 3, 181-193, doi:10.5194/acp-3-181-2003, 2003.

Jenkin, M. E., Wyche, K. P., Evans, C. J., Carr, T., Monks, P. S., Alfarra, M. R., Barley, M. H., McFiggans, G. B., Young, J. C., and Rickard, A. R.: Development and chamber evaluation of the MCM v3.2 degradation scheme for B-caryophyllene, Atmos. Chem. Phys., 12, 5275-5308, doi:10.5194/acp-12-5275-2012, 2012.

Jiang, J., Attoui, M., Heim M., Brunelli, N. A., McMurry, P. H., Kasper, G., Flagan, R. C., Giapis, K., and Mouret, G.: Transfer functions and penetrations of five differential mobility analyzers for sub-2 $\mathrm{nm}$ particle classification, Aerosol Sci. Technol., 45, 480-492, 2011.

Kalberer, M., Paulsen, D., Sax, M., Steinbacher, M., Dommen, J., Prevot, A. S. H., Fisseha, R., Weingartner, E., Frankevich, V., Zenobi, R., and Baltensperger, U.: Identification of polymers as major components of atmospheric organic aerosols, Science, 303, 1659-1662, 2004.

Karlsson, M. N. A. and Martinsson, B. G.: Methods to measure and predict the transfer function size dependence of individual DMAs, J. Aerosol Sci., 34, 603-625, 2003.

Kerminen, V. M., and Kulmala, M.: Analytical formulae connecting the "real" and the"apparent" nucleation rate and the nuclei number concentration for atmospheric nucleation events, J. Aerosol Sci., 33, 609-622, 2002.

Kesselmeier, J. and Staudt, M. A.: Biogenic volatile organic compounds (VOC): an overview on emission, physiology and ecology, J. Atmos. Chem., 33, 23-88, 1999

Kestel, P.: Nukleationsstudie zur Ozonolyse von cis-2-Buten, Master's thesis, J. W. Goethe-University, Frankfurt (Main), 2013.

Kiendler-Scharr, A., Wildt, J., Dal Maso, M., Hohaus, T., Kleist, E., Mentel, T. F., Tillmann, R., Uerlings, R., Schurr, U., and Wahner, A.: New particle formation in forests inhibited by isoprene emissions, Nature, 461, 381-384, 2009.

Kirkby, J., Curtius, J., Almeida, J., Dunne, E., Duplissy, J., Ehrhart, S., Franchin, A., Gagné, S., Ickes, L., Kürten, A., Kupc, A., Metzger, A., Riccobono, F., Rondo, L., Schobesberger, S., Tsagkogeorgas, G., Wimmer, D., Amorim, A., 
Bianchi, F., Breitenlechner, M., David, A., Dommen, J., Downard, A., Ehn, M., Flagan, R. C., Haider, S., Hansel, A., Hauser, D., Jud, W., Junninen, H., Kreissl, F., Kvashin, A., Laaksonen, A., Lehtipalo, K., Lima, J., Lovejoy, E. R., Makhmutov, V., Mathot, S., Mikkilä, J., Minginette, P., Mogo, S., Nieminen, T., Onnela, A., Pereira, P., Petäjä, T., Schnitzhofer, R., Seinfeld, J. H., Sipilä, M., Stozhkov, Y., Stratmann, F., Tomé, A., Vanhanen, J., Viisanen, Y., Vrtala, A., Wagner, P. E., Walther, H., Weingartner, E., Wex, H., Winkler, P. M., Carslaw, K. S., Worsnop, D. R., Baltensperger, U., and Kulmala, M.: Role of sulphuric acid, ammonia and galactic cosmic rays in atmospheric aerosol nucleation, Nature, 476, 429-433, 2011.

Kristensen, K., Cui, T., Zhang, H., Gold, A., Glasius, M., and Surratt, J. D.: Dimers in $\alpha$-pinene secondary organic aerosol: effect of hydroxyl radical, ozone, relative humidity and aerosol acidity, Atmos. Chem. Phys., 14, 4201-4218, doi:10.5194/acp-14-42012014, 2014.

Kulmala, M., Dal Maso, M., Mäkelä, J. M., Pirjola, L., Väkevä, M., Aalto, P., Miikkulainen, P., Hämeri, K., and O'Dowd, C. D.: On the formation, growth and composition of nucleation mode particles, Tellus B, 53, 479-490, 2001.

Kulmala, M., Kerminen, V.-M., Anttila, T., Laaksonen, A., and O'Dowd, C.: Organic aerosol formation via sulphate cluster activation, J. Geophys. Res., 109, D04205, doi:10.1029/2003JD003961, 2004a.

Kulmala, M., Laakso, L., Lehtinen, K. E. J., Riipinen, I., Dal Maso, M., Anttila, T., Kerminen, V.-M., Hõrrak, U., Vana, M., and Tammet, H.: Initial steps of aerosol growth, Atmos. Chem. Phys., 4, 2553-2560, doi:10.5194/acp-4-2553-2004, 2004b.

Kulmala, M., Suni, T., Lehtinen, K. E. J., Dal Maso, M., Boy, M., Reissell, A., Rannik, Ü., Aalto, P., Keronen, P., Hakola, H., Bäck, J., Hoffmann, T., Vesala, T., and Hari, P.: A new feedback mechanism linking forests, aerosols, and climate, Atmos. Chem. Phys., 4, 557-562, doi:10.5194/acp-4-557-2004, 2004c.

Kulmala, M., Vehkamäki, H., Petäjä, T., Dal Maso, M., Lauri, A., Kerminen, V.-M., Birmili, W., and McMurry, P. H.: Formation and growth rates of ultrafine atmospheric particles: a review of observations, J. Aerosol Sci., 35, 143-176, 2004d.

Kulmala, M., Lehtinen, K. E. J., and Laaksonen, A.: Cluster activation theory as an explanation of the linear dependence between formation rate of $3 \mathrm{~nm}$ particles and sulphuric acid concentration, Atmos. Chem. Phys., 6, 787-793, doi:10.5194/acp-6-787-2006, 2006.

Laakso, L., Anttila, T., Lehtinen, K. E. J., Aalto, P. P., Kulmala, M., Hõrrak, U., Paatero, J., Hanke, M., and Arnold, F.: Kinetic nucleation and ions in boreal forest particle formation events, Atmos. Chem. Phys., 4, 2353-2366, doi:10.5194/acp-4-2353-2004, 2004.

Lin, Y.-H., Zhang, Z., Docherty, K. S., Zhang, H., Budisulistiorini, S. H., Rubitschun, C. L., Shaw, S. L., Knipping, E. M., Edgerton, E. S., Kleindienst, T. E., Gold, A., Surratt, J. D.: Isoprene epoxydiols as precursors to secondary organic aerosol formation: Acid-catalyzed reactive uptake studies with authentic compounds, Environ. Sci. Technol., 46, 250-258, 2012.

Mauldin III., R. L., Berndt, T., Sipilä, M., Paasonen, P., Petäjä, T., Kim, S., Kurtén, T., Stratmann, F., Kerminen, V.-M., and Kulmala, M.: A new atmospherically relevant oxidant of sulphur dioxide, Nature, 488, 193-197, 2013.
McFiggans, G., Coe, H., Burgess, R., Allan, J., Cubison, M., Alfarra, M. R., Saunders, R., Saiz-Lopez, A., Plane, J. M. C., Wevill, D., Carpenter, L., Rickard, A. R., and Monks, P. S.: Direct evidence for coastal iodine particles from Laminaria macroalgae - linkage to emissions of molecular iodine, Atmos. Chem. Phys., 4, 701-713, doi:10.5194/acp-4-701-2004, 2004.

Metzger, A., Verheggen, B., Dommen, J., Duplissy, J., Prevot, A. S. H., Weingartner, E., Riipinen, I., Kulmala, M., Spracklen, D. V., Carslaw, K. S., and Baltensperger, U.: Evidence for the role of organics in aerosol particle formation under atmospheric conditions, P. Natl. Acad. Sci. USA, 107, 6646-6651, 2010.

Nguyen, T. B., Coggon, M. M., Flagan, R. C., Seinfeld, J. H.: Reactive uptake and photo-fenton oxidation of glycolaldehyde in aerosol liquid water, Environ. Sci. Technol., 47, 4307-4316, 2013.

Nieminen, T., Dal Maso, M., Petäjä, T., Aalto, P. P., Kerminen, V.M., Hari, P., and Kulmala, M.: Trends on atmospheric new particle formation - 16 years of observations in boreal forest, Geophysical Research Abstracts, vol. 14, EGU2012-10036, EGU General Assembly, 2012.

Niinemets, Ü., Arneth, A., Kuhn, U., Monson, R. K., Peñuelas, J., and Staudt, M.: The emission factor of volatile isoprenoids: stress, acclimation, and developmental responses, Biogeosciences, 7, 2203-2223, doi:10.5194/bg-7-2203-2010, 2010.

Nölscher, A. C., Williams, J., Sinha, V., Custer, T., Song, W., Johnson, A. M., Axinte, R., Bozem, H., Fischer, H., Pouvesle, N., Phillips, G., Crowley, J. N., Rantala, P., Rinne, J., Kulmala, M., Gonzales, D., Valverde-Canossa, J., Vogel, A., Hoffmann, T., Ouwersloot, H. G., Vilà-Guerau de Arellano, J., and Lelieveld, J.: Summertime total $\mathrm{OH}$ reactivity measurements from boreal forest during HUMPPA-COPEC 2010, Atmos. Chem. Phys., 12, 8257-8270, doi:10.5194/acp-12-8257-2012, 2012.

Nölscher, A.C., Bourtsoukidis, E., Bonn, B., Kesselmeier, J., Lelieveld, J., and Williams, J.: Seasonal measurements of total $\mathrm{OH}$ reactivity emission rates from Norway spruce in 2011, Biogeosciences, 10, 4241-4257, doi:10.5194/bg-10-4241-2013, 2013.

O'Dowd, C. D. and Hoffmann, T.: Coastal new particle fomation: a review of the current state of the art, Environ. Chem., 2, 245255, 2005.

O’Dowd, C. D., Jimenez, J. L., Bahreini, R., Flagan, R. C., Seinfeld, J. H., Hämeri, K., Pirjola, L., Kulmala, M., Jennings, S. G., and Hoffmann, T.: Marine aerosol formation from biogenic iodine emissions, Nature, 417, 632-636, 2001.

Paasonen, P., Olenius, T., Kupiainen, O., Kurtén, T., Petäjä, T., Birmili, W., Hamed, A., Hu, M., Huey, L. G., Plass-Duelmer, C., Smith, J. N., Wiedensohler, A., Loukonen, V., McGrath, M. J., Ortega, I. K., Laaksonen, A., Vehkamäki, H., Kerminen, V.-M., and Kulmala, M.: On the formation of sulphuric acid - amine clusters in varying atmospheric conditions and its influence on atmospheric new particle formation, Atmos. Chem. Phys., 12, 9113-9133, doi:10.5194/acp-12-9113-2012, 2012.

Paasonen, P., Asmi, A., Petäjä, T., Kajos, M. K., Äijälä, M., Junninen, H., Holst, T., Abbatt, J. P. D., Arneth, A., Birmili, W., Denier van der Gon, H., Hamed, A., Hoffer, A., Laakso, L., Laaksonen, A., Leaitch, W. R., Plass-Dülmer, C., Pryor, S. C., Räisänen, P., Swietlicki, E., Wiedensohler, A., Worsnop, D. R., Kerminen, V.-M., and Kulmala, M.: Warming-induced increase in 
aerosol number concentration likely to moderate climate change, Nat. Geosci., 6, 438-442, 2013.

Pankow, J. F.: An absorption model of gas/particle partitioning of organic compounds in the atmosphere, Atmos Environ., 28, 185188, 1994.

Pirjola, L. and Kulmala, M.: Modelling the formation of $\mathrm{H}_{2} \mathrm{SO}_{4}-\mathrm{H}_{2} \mathrm{O}$ particles in rural, urban and marine conditions, Atmos. Res., 46, 321-347, 1998.

Riipinen, I., Sihto, S.-L., Kulmala, M., Arnold, F., Dal Maso, M., Birmili, W., Saarnio, K., Teinilä, K., Kerminen, V.-M., Laaksonen, A., and Lehtinen, K. E. J.: Connections between atmospheric sulphuric acid and new particle formation during QUEST III-IV campaigns in Heidelberg and Hyytiälä, Atmos. Chem. Phys., 7, 1899-1914, doi:10.5194/acp-7-1899-2007, 2007.

Rohrer, F. and Berresheim, H.: Strong correlation between levels of tropospheric hydroxyl radicals and solar ultraviolet radiation, Nature, 442, 184-187, 2006.

Ryding, M. J., Å. M. Jonsson, Zatula, A. S., Andersson, P. U., and Uggerud, E.: Reactions of $\mathrm{H}^{+}$(pyridine $)_{m}\left(\mathrm{H}_{2} \mathrm{O}\right)_{n}$ and $\mathrm{H}^{+}\left(\mathrm{NH}_{3}\right)_{1}$ (pyridine $)_{m}\left(\mathrm{H}_{2} \mathrm{O}\right)_{n}$ with $\mathrm{NH}_{3}$ : experiments and kinetic modelling, Atmos. Chem. Phys., 12, 2809-2822, doi:10.5194/acp-12-2809-2012, 2012.

Saunders, S. M., Jenkin, M. E., Derwent, R. G., and Pilling, M. J.: Protocol for the development of the Master Chemical Mechanism, MCM v3 (Part A): tropospheric degradation of nonaromatic volatile organic compounds, Atmos. Chem. Phys., 3, 161-180, doi:10.5194/acp-3-161-2003, 2003.

Seinfeld, J. H. and Pandis, S. N.: Atmospheric Chemistry and Physics: From Air Pollution to Climate Change, 2nd edn., J. Wiley \& Sons, 2006.

Shu, Y. and Atkinson, R.: Rate constants for the gas-phase reactions of $\mathrm{O}_{3}$ with a series of terpenes and $\mathrm{OH}$ radical formation from the $\mathrm{O}_{3}$ reactions with sesquiterpenes at $296 \pm 2 \mathrm{~K}$, Int. J. Chem. Kinet., 26, 1193-1205, 1994.

Sihto, S.-L., Kulmala, M., Kerminen, V.-M., Dal Maso, M., Petäjä, T., Riipinen, I., Korhonen, H., Arnold, F., Janson, R., Boy, M., Laaksonen, A., and Lehtinen, K. E. J.: Atmospheric sulphuric acid and aerosol formation: implications from atmospheric measurements for nucleation and early growth mechanisms, Atmos. Chem. Phys., 6, 4079-4091, doi:10.5194/acp-64079-2006, 2006.

Sogachev, A., Menzhulin, G., Heimann, M., and Lloyd, J.: A simple three dimensional canopy-planetary boundary layer simulation model for scalar concentrations and fluxes, Tellus B, 54, 784 819,2002
Sogachev, A., Rannik, Ü., and Vesala, T.: Flux footprints over complex terrain covered by heterogeneous forest, Agr. Forest Meteorol., 127, 143-158, 2004.

Sogachev, A., Leclerc, M. Y., Zhang, G., Rannik, Ü., and Vesala, T.: $\mathrm{CO}_{2}$ fluxes near a forest edge: a numerical study, Ecol. Appl., 18, 1454-1469, 2008.

Sogachev, A., Kelly, M., and Leclerc, M. Y.: Consistent twoequation closure modeling for atmospheric research: buoyancy and vegetation implementations, Bound.-Lay. Meteorol., 145, 307-327, 2012.

Spracklen, D. V., Bonn, B., and Carslaw, K. S.: Boreal forests, aerosols and the impacts on clouds and climate, Philos. T. R. Soc. A, 366, 4613-4626, 2008.

Stolzenburg, M. R. and McMurry, P. H.: Equations governing single and tandem DMA configurations and a new lognormal approximation to the transfer function, Aerosol Sci. Tech., 42, 421-432, 2008.

Surratt, J. D., Chan, A. W. H., Eddingsaas, N. C., Chan, M., Loza, C. L., Kwan, A. J., Hersey, S. P., Flagan, R. C., Wennberg, P. O. and Seinfeld, J. H.: Reactive intermediates revealed in secondary organic aerosol formation from isoprene, P. Natl. Acad. Sci. USA, 107, 6640-6645, 2010.

Weber, R. J., McMurry, P. H., Mauldin III, R. L., Tanner, D., Eisele, F. L., Clarke, A. D., and Kapustin, V. N.: New particle formation in the remote troposphere: a comparison of observations at various sites, Geophys. Res. Lett., 26, 307-310, 1999.

Wiedensohler, A. and Fissan, H. J.: Aerosol charging in high purity gases, J. Aerosol Sci., 19, 867-870, 1988.

Wolf, J. L., Suhm, M., and Zeuch, T.: Suppressed particle formation by kinetically controlled ozone removal: revealing the role of transient-species chemistry during alkene ozonolysis, Angew. Chem., 48, 2231-2235, 2009.

Wolf, L., Richters, S., Pecher, J., and Zeuch, T.: Pressure dependent mechanistic branching in the formation pathways of secondary organic aerosol from cyclic-alkene gas-phase ozonolysis, Phys. Chem. Chem. Phys., 13, 10952-10964, 2011.

Zappoli, S., Andracchio, A., Fuzzi, S., Facchini, M. C., Gelencser, A., Kiss, G., Krivacsy, Z., Molnar, A., Meszaros, E., Hansson, H. C., Rosman, K., and Zebuhr, Y.: Inorganic, organic and macromolecular components of fine aerosol in different areas of europe in relation to their water solubility, Atmos. Environ., 33, 2733-2743, 1999.

Zhang, R., Khalizov, A., Wang, L., Hu, M., and Xu, W.: Nucleation and growth of nanoparticles in the atmosphere, Chem. Rev., 112, 1957-2011, 2012. 